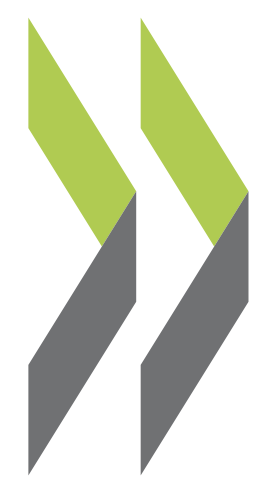

OECD Economics Department Working Papers No. 93

A Macroeconomic Model for Debt Analysis of the Latin America Region and Debt Accounting Models for the Highly Indebted Countries

\section{Peter Dittus,} Paul S. O'Brien 


\section{OECD \\ DEPARTMENT \\ OF ECONOMICS AND STATISTICS}

\section{WORKING PAPERS}

No. 93: A MACROECONOMIC MODEL FOR DEBT ANALYSIS OF THE IATIN AMERICA REGION AND DEBT ACCOUNTING MODELS FOR THE HIGHLY INDEBTED COUNTRIES

by

Peter Dittus

Central and Eastern Europe Division

Paul S. O'Brien

Country Studies Division II

February 1991

ㅇD도

濡苚需;

OESD 

GENERAL DISTRIBUTION

\title{
BCONOYICS AND STATISTICS DEPARTMIRTI
}

\author{
WORRING PAPERS
}

\begin{abstract}
This series of Working Papers is designed to make available, to a wider readership. selected studies which the Department has prepared for use within OECD. Authorship is generally collective, but main individual authors are named. The Papers are generally available in their original language, English or French, with a summary in the other.

Comment on the Papers is invited, and may be sent to OECD, Department of Economics and Statistics, 2 rue André Pascal, 75775 Paris Cedex 16. France. Additional copies of the Papers on a limited basis can be forwarded on request.
\end{abstract}

ORGANISATION FOR ECONOMIC CO-OPERATION AND DEVELOPMENT 
Throughout the 1980 s the problem of developing country debt was a recurring theme in international debate. Discussion was often hampered by the the lack of an empirically-based modelling framework with which to discuss the interaction between developments and policies in OECD countries and those in debtor countries. This paper provides such a framework for Latin America, in the form of macro-economic models for the major countries in that region which are linked to the OECD's INTERLINK model of the industrialised countries. Using these models in combination it is possible to simulate the effects of, for example, fiscal policy tightening in OECD countries, on the output, trade and credit-worthiness of Latin American countries; in the same simulation INTERLINK provides details of the effects of the same policy change on OECD countries - both direct effects and via feedback to OECD countries from Latin America. This paper discusses the structure and estimation of the models for Latin America, describing the relationship with INTERLINK, and illustrates how the models can be used to analyse certain shocks and policy changes. 


\section{A Macroeconomic Model for Debt Analysis of the Latin America Region and Debt Accounting Models for the Highly Indebted Countries}

by

Peter Dittus and Paul O'Brien

Central and Eastem Europe Division and

Country Studies Division II

February 1991

This project was made possible by a special grant from the Norwegian government, whose assistance is gratefully acknowledged. The authors wish to thank Laure Meuro for excellent research assistance. They are also graieful for comments from Hans Blommestein, Val Koromzay, Andrew Dean, Jeff Shafer, Pete Richardson, Paul Atkinson, Nick Vanston, and other colleagues in the OECD Economics and Statistics Department. The views expressed reflect their own opinions and do not necessarily represent those of the OECD or of the governments of its member countries. 


\section{A Macroeconomic Model for Debt Analysis of the Latin America Region and Debt Accounting Models for the Highly Indebted Countries}

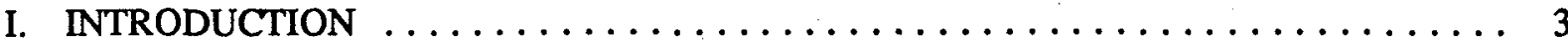

II. MODELLING $\ldots \ldots \ldots \ldots \ldots \ldots \ldots \ldots \ldots \ldots \ldots \ldots \ldots \ldots \ldots \ldots, 4$

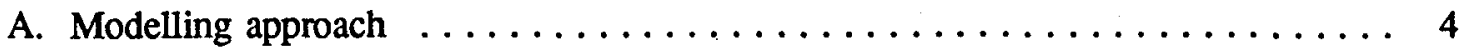

B. DEMOD: macroeconomic models for Latin America $\ldots \ldots \ldots \ldots \ldots \ldots \ldots$. 5

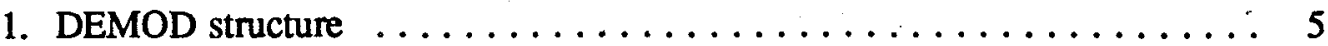

(a) The output block $\ldots \ldots \ldots \ldots \ldots \ldots \ldots \ldots \ldots \ldots, 6$

(b) The trade block $\ldots \ldots \ldots \ldots \ldots \ldots \ldots \ldots \ldots \ldots \ldots, 8$

(c) The debt block $\ldots \ldots \ldots \ldots \ldots \ldots \ldots \ldots \ldots \ldots, 9$

2. DEMOD parameter estimation and tracking performance $\ldots \ldots \ldots \ldots .10$

(a) Parameter estimation $\ldots \ldots \ldots \ldots \ldots \ldots \ldots \ldots \ldots, 10$

(b) Tracking behavior $\ldots \ldots \ldots \ldots \ldots \ldots \ldots \ldots \ldots \ldots \ldots \ldots$

(c) The baseline for simulations $\ldots \ldots \ldots \ldots \ldots \ldots \ldots \ldots 13$

C. The HIC debt models $\ldots \ldots \ldots \ldots \ldots \ldots \ldots \ldots \ldots \ldots \ldots \ldots \ldots \ldots$

1. Linkage to INTERLINK $\ldots \ldots \ldots \ldots \ldots \ldots \ldots \ldots \ldots \ldots \ldots, 14$

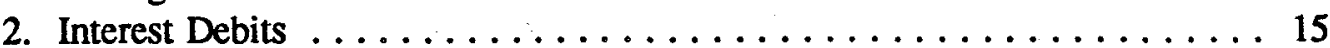

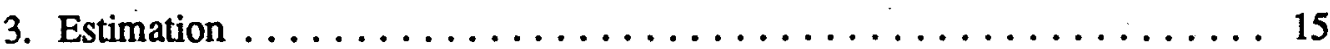

4. Tracking performance of the investment income equations $\ldots \ldots \ldots \ldots 17$

III. SIMULATION PROPERTIES $\ldots \ldots \ldots \ldots \ldots \ldots \ldots \ldots \ldots \ldots \ldots \ldots \ldots \ldots \ldots$

A. Increase of the short term interest rate $\ldots \ldots \ldots \ldots \ldots \ldots \ldots \ldots \ldots, 18$

B. Increase of OECD GDP by one per cent $\ldots \ldots \ldots \ldots \ldots \ldots \ldots \ldots \ldots, 19$

C. Increase of net flows $\ldots \ldots \ldots \ldots \ldots \ldots \ldots \ldots \ldots \ldots \ldots \ldots, 20$

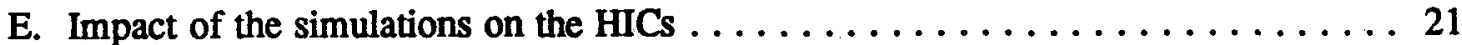

F. The importance of feedback from Latin America for OECD economies ....... 22

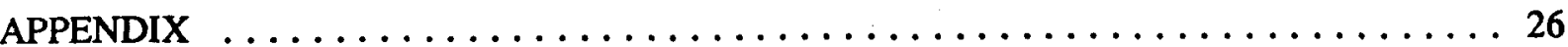

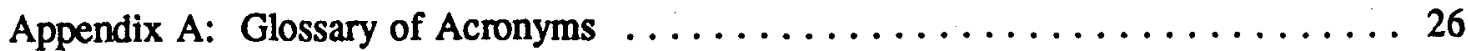

Appendix B: DEMOD Model Listings $\ldots \ldots \ldots \ldots \ldots \ldots \ldots \ldots \ldots \ldots, 30$

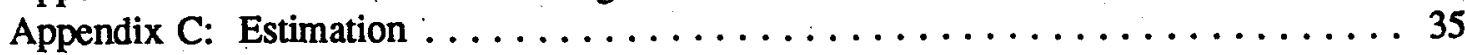

Appendix D: Simulation Results $\ldots \ldots \ldots \ldots \ldots \ldots \ldots \ldots \ldots \ldots \ldots, \ldots 1$

Appendix E: HIC Models $\ldots \ldots \ldots \ldots \ldots \ldots \ldots \ldots \ldots \ldots \ldots \ldots \ldots, 44$ 


\section{INTRODUCTION}

1. During the 1980 s, following the Mexican payments crisis of August 1982, a number of debt "plans" and "strategies" have been introduced, but overall progress in resolving the situation has been slow. This paper results from a project to investigate the relationship between macroeconomic developments in OECD countries and those in debtor countries. The aim is to develop tools that can help to throw light on the importance of international linkages, including those between OECD and debtor countries, in order to understand better why many of the hopes and expectations of the various debt plans have not been realised.

2. This paper presents a set of models for Latin America (DEMOD) that can be used to analyze the impact of the world macroeconomy on the economies of Latin America; these have been designed to focus in particular on growth and debt servicing capacity and to trace the development of creditworthiness indicators 1 . In addition, debt accounting models for the highly indebted countries (HICs) have been developed. The difference between this and many other debt models is its integration into a world macroeconomic model, the OECD's INTERLINK model. This assures consistency of macroeconomic policy assumptions in OECD countries and economic aggregates, and incorporates feedback between OECD and Latin America by model design.

3. Building on the strengths of INTERLINK - its global character, providing explicit modelling of intemational linkages of trade volumes and prices, as well as of interest and exchange rates - and based on estimated relationships, DEMOD also provides direct links between the debt burden and economic performance of Latin American countries, a feature less frequently observed in models of this kind. Its break-down into individual country modules allows a closer look to be taken at four countries of special interest: Brazil, Mexico, Argentina and Chile.

4. The paper is in three parts. Following the introduction, section II describes DEMOD and the HIC debt accounting models. This section presents choices that were made and the trade-offs involved; discusses the model structure and the key relationships that drive the model; introduces the determination of parameters and the establishment of a medium term baseline; and presents tracking capabilities of the models. The marginal properties of the model are explored in section III with the help of standard shocks. This section also contains a empirical evaluation of the importance of the feedback loop from Latin America to OECD countries by comparing a no-feedback situation against the INTERLINK trade equations and the DEMOD country modules. A complete model listing, including estimation results, is contained in the appendix. 


\section{MODELLING}

\section{A. Modelling approach}

5. The major purpose of DEMOD is the analysis of the impact of OECD economic policies on middle-income debtors, and a quantification of the macroeconomic linkages. In particular, we wish (i) to extend the analysis of the impact of OECD economies upon non-OECD debtor countries beyond INTERLINK's restriction to group data and external indicators; (ii) to enhance the reliability of INTERLINK's feedback relationships by taking into account some explicit domestic considerations for non-OECD countries; (iii) to enhance the quality of the debt-accounting structure.

6. Given these aims, decisions on three key elements of modelling strategy are necessary. Should the models be "stand-alone" models, which would allow considerable freedom in specification and choice of data sources, or should they be linked to formally to a world model? Should we concentrate on individual country models, which may be time consuming, or use a regional aggregate which may allow more time for detailed specification? Should they be fully specified macroeconomic models or are reduced from relationships adequate?

7. Since the models are intended to be used to analyse interaction between debtor countries and the world economy, it is a clear advantage to design them from the beginning to interact with a world model, in this case INTERLINK. This immediately gives some constraints: the world environment variables used as external factors for the debtor countries must be available in the INTERLINK structure, and the DEMOD models must produce output that can be fed into INTERLINK. This decision also influences the choice of countries to be modelled.

8. INTERLINK treats non-OECD countries in highly aggregate form ${ }^{2}$, using country groups defined on a geographical basis. No one group contains all the important debtor countries. The Latin America grouping contains several of the most important middle-income debtor countries and we have concentrated on this group for DEMOD. This group contains 30 countries; while it would be infeasible to model each one individually, some disaggregation is desirable. Focusing on some individual countries has some obvious advantages. It allows individual country differences - such as different countries' ability to transform additional external resources into output growth - to be taken into account. Differences between countries with respect to capital exports can also be of interest to policy-makers. This focus is also a prerequisite for linking country-specific information to the macroeconomic behaviour of Latin America as a whole, an advantage in the context of the OECD's periodic forecasting exercise. Individual country models also provide flexibility for changing country coverage or redefining regions. While more costly in terms of resources, these have been kept down by using an identical structure for the different models.

9. Obvious countries to focus on are Brazil and Mexico, given their size and importance in the region; Argentina, a rather badly performing country, and Chile, a rather successful adjuster, were also chosen. The remainder of LAT $^{4}$ is modelled as the aggregate of 15 other countries 5 . An overview 
of the importance of different countries within LAT is provided in Chart 1. Brazil and Mexico alone account for about 70 per cent of LAT GDP, and almost 60 per cent of total debt outstanding and disbursed. Chile accounts for around 5 per cent, and Argentina for around 10 per cent, of LAT. The trade participation ratio (exports plus imports as a proportion of GDP) varies between 16 per cent for Brazil and 35 per cent for Chile; the overall LAT average is 21 per cent. Venezuela is not included, because it is part of the OPEC group in the INTERLINK country groupings.

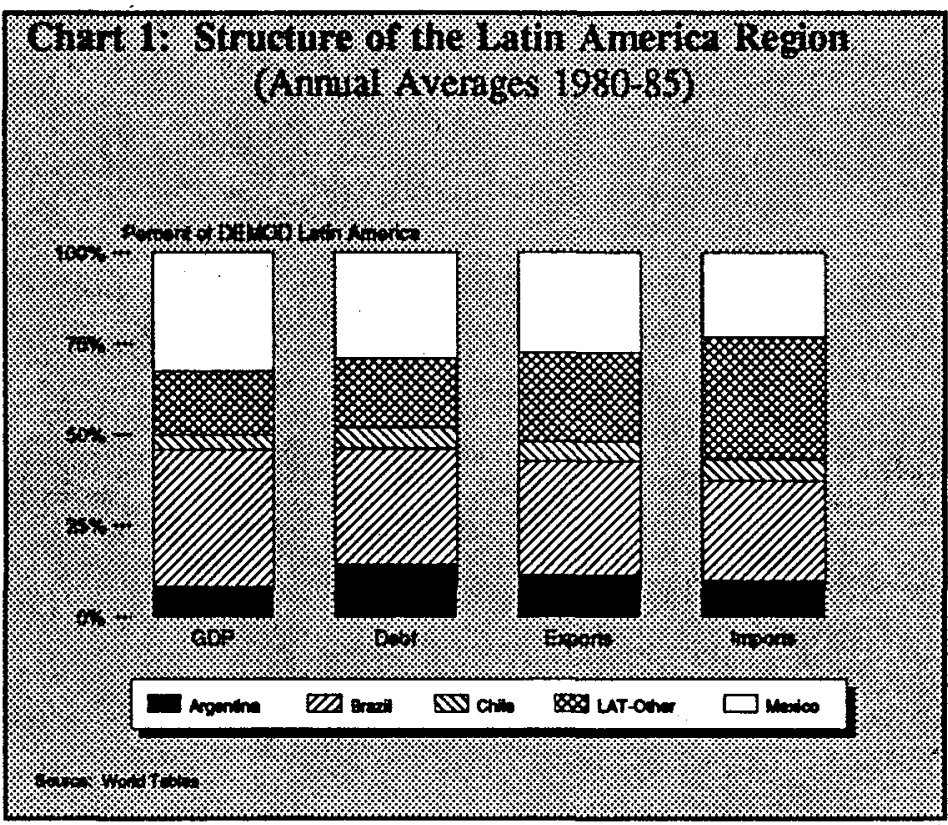

10. The third key element is the degree of detailed structural modelling done for each country model. Our approach was to provide the minimum structure necessary to capture some of the essential aspects of the mechanisms by which external shocks affect domestic performance and creditworthiness. External capital flows and interest rates, the level of world activity, and of exchange rates and international trade prices are the variables whose influences we wish to trace, and the models have been designed with this in mind. Not all the major debtors are covered by DEMOD: therefore an additional set of debt-accounting models was constructed to cover the 17 "Highly Indebted Countries". The structure of these models is set out on pages $14 \mathrm{ff}$.

\section{B. DEMOD: macroeconomic models for Latin America}

\section{DEMOD structure}

11. DEMOD features endogenous output determination. However, the output block has been kept small, designed to capture just a few essential aspects of extemal shocks on domestic growth performance: extemal capital flows influence fixed investment; on the demand side investment has an important effect on actual output while on the supply side it influences the capital stock and potential output. Exports affect actual output via their effect on demand while imports are influenced directly by demand but also by the degree of capacity utilisation. The domestic financial sector has not been modelled.

12. DEMOD consists of five country modules - Brazil, Mexico, Chile, Argentina, and the aggregate of 15 smaller countries - each module having the same structural skeleton, presented in 


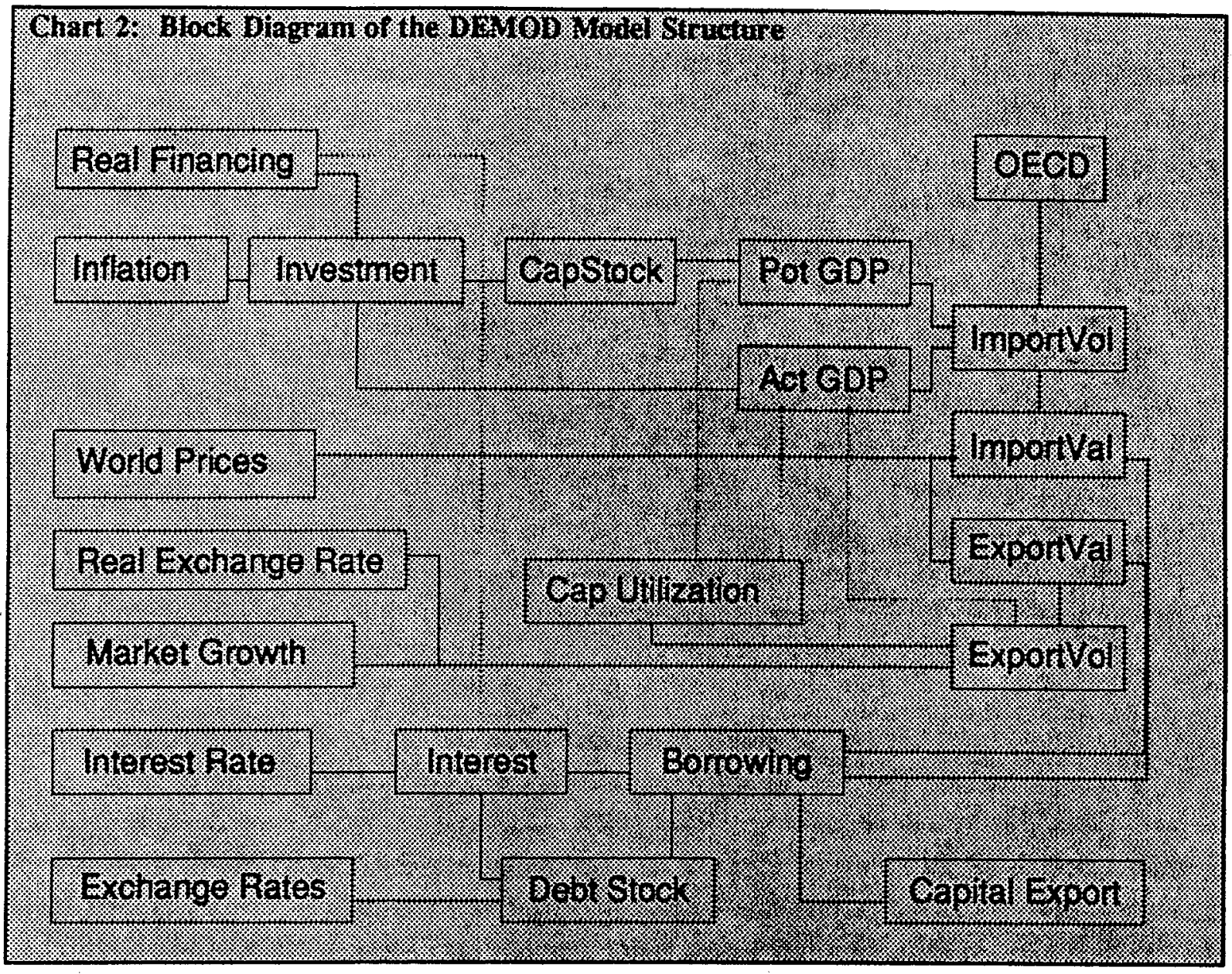

Chart 2. Variables that country models treat as exogenous are on the left hand side. These include the "economic environment" variables that DEMOD takes directly from INTERLINK: Prices for imports and exports, market growth for Latin America, the US short term interest rate, and the nominal effective US Dollar exchange rate. Additional exogenous variables are the inflation rate and the real exchange rate vis-a-vis the US Dollar. The DEMOD models consists of three blocks: the output block, the trade block and the debt block, which we discuss in turn.

\section{(a) The output block}

13. The output block calculates potential and actual output and it is here that the main domestic macroeconomic relationships referred to above are incorporated. Variations in potential output depend only on the capital stock; both inreases in the labor force and technological progress are represented by a time trend. The functional form is log-linear in potential output, the capital stock and the time trend, with the elasticity of potential output with respect to the capital stock assumed ${ }^{6}$ to be 0.4 . Capital stock data were not available and have been derived under the assumption, fairly common practice where reliable data is unavailable, that the capital stock was three times GDP in 1975, and 
that it increases every year by gross domestic investment minus depreciation. The annual depreciation rate is assumed to be 5 per cent.

14. Actual output, rather than being derived - as for example in INTERLINK - from the sum of its expenditure components, is determined directly in a partially reduced form as a function of investment and exports. A structural formulation of the output block - with more detailed modelling of expenditure components, while desirable, goes beyond what was considered necessary and feasible for DEMOD.

15. Of domestic demand components, only investment is determined endogenously, permitting endogenous variation in the capital stock and potential output, as well as demand and actual output. We found no significant role for the real interest rate in the investment functions. This may have been for lack of an appropriate interest rate series and information on appropriate tax adjustments etc. But it seems more likely that, most of the time, interest rates are low on the list of factors taken into account in investment decisions in these countries. Much better results were obtained treating investment as savings constrained: investment is a function of activity (GDP and/or exports, proxying demand pressure and availability of internal finance) and real net external finance.

16. In addition to activity and net external flows, inflation is an important conditioning variable in the investment equations for Mexico and LAT-other, acting as a proxy for the macroeconomic framework. A major weakness of this version of DEMOD is the absence of any variable representing government policy, other than the rate of inflation. Lack of adequate and easily available data ruled out the use of a direct measure of fiscal or monetary policy at this stage ${ }^{7}$. The inflation rate was used, not in the expectation that one could use it to study the impact of changes in policy, but as a crude conditioning variable, in an attempt to improve estimates of other parameters in the equation. ${ }^{8}$

17. Real net external finance is defined as inflows of long term finance net of amortisation and interest payments, expressed in constant dollars. Thus investment depends on foreign interest rates indirectly, via their effect on available finance. Brazil is an exception here; it was not possible to identify a positive correlation between extemal finance and domestic investment. The debt:GDP ratio is quite strongly negatively correlated with investment in Brazil, however, and has been included in the equation.

18. The link between net real lending and investment is a key feature of the output block. Latin America is modelled as being finance constrained. But this constraint is a "soft constraint." DEMOD does not impose that additional exports or finance lead to an exactly equivalent rise in either investment or imports. Such additional finance will be used to increase imports, but part may also implicitly be used to increase reserve holdings or other assets abroad. The propensity of different countries with respect to these options is different, and embodied in the models' parameters. An additional variation compared with a strict finance-contrained model is that the reaction of imports to changes in exports may differ from the reaction to changes in external finance. Thus DEMOD retains the basic idea that Latin American countries are finance-constrained, but does not impose this strictly'. 
19. In this context another choice in model design is of interest. There is agreement that the reduction in real lending that occurred in 1981/82 was a key factor in the decrease of investiment and the ensuing slowing of growth. There is less agreement with regard to the mechanism by which this shock was transmitted. One possibility is that reduced net lending led to reduced imports, which in turn then caused declines in investment. The other possibility is that reduced net lending led to cancellations of investment projects, which in turn led to declining imports. While it is quite likely that both channels are at work simultaneously, the data do not offer the scope for incorporating both into the model at the same time. For DEMOD, using a real net lending variable to determine investment was the preferred solution, in particular because such a model tracks better. A model using the alternative approache gave roughly the same current account changes in response to a given shock to extemal finance.

\section{(b) The trade block}

20. DEMOD breaks trade into four categories: manufactures, raw materials and food, energy, and non-factor services. These categories match exactly the commodity breakdown of INTERLINK's trade sector (except that INTERLINK separates food and other raw materials). Export volumes depend basically on market growth, derived from INTERLINK modified by domestic capacity utilization - the ratio of actual to potential output. Increased capacity utilization means increased domestic demand for goods - both as inputs for domestic production and for direct consumption - and hence reduced supply for exports ${ }^{10}$.

21. In standard export functions, as in INTERLINK, competitiveness is a key variable determining trade patterns. Here it was only in the case of Brazil that we succeeded in establishing a statistically significant competitive effect on exports, in the form of a real exchange rate variable. The volume of Mexico's oil exports appears to have little to do with market growth, but more with supply potential and possibly strategic considerations. The value of oil exports varies with oil prices but volume is taken to be exogenous.

22. Imports are separated into the same commodity categories as exports. In each category, import volumes are determined by domestic activity variables and capacity utilization. Domestic activity variables are one or several of the following: actual output, potential output, the difference between actual and potential output, and investment. Again, as for exports, we did not find a significant competitiveness variable, and there are therefore no price terms in the import equations.

23. As discussed above, DEMOD treats Latin American countries as finance constrained; but this constraint is "soft": imports are not directly determined by the amount of export revenue and capital flows available. Rather these latter variables affect other expenditures (via the investment and output equations) which in turn have an important impact on import behaviour. 
24. Trade prices determined in INTERLINK, and therefore the same (in each category of trade) for each of the DEMOD countries, are used to calculate the dollar value of imports and exports.

\section{(c) The debt block}

25. The debt block is a standard debt accounting module. It calculates debt and asset stocks dynamically over time, and uses them to determine factor service payments. Creditworthiness indicators like the debt to GDP ratio, the debt to export ratio, and the interest to export ratio are also calculated in this block.

26. Changes in debt stocks depend on two factors: net borrowing, and valuation adjustments. Valuation adjustments are necessary because part of the external liabilities are not in US dollars, but DEMOD measures debt in US dollars. Changes in the effective nominal rate (EXCHE from INTERLINK) of the US dollar vis-a-vis other currencies are used, together with an assumed non-dollar share of debt, to derive valuation adjustments to the US dollar stock of debt.

27. Capital exports are (mostly) unobserved but can be calculated ex post as a residual, given the valuation adjusted change in debt stocks, net direct foreign investment, reserve changes and the current account balance. This follows from the identity for net borrowing, that is total borrowing less amortization payments, defined as:

$\begin{array}{ll}\text { Net borrowing = } & \text { Reserve Change } \\ & + \text { Current Account Deficit } \\ & + \text { Capital Exports } \\ & - \text { Net (inward) Direct Foreign Investment }\end{array}$

DEMOD links reserve changes to imports and the current account through standard equations that assume a certain - country specific - reserve cover for imports. The current account deficit is calculated as the sum of the trade balance, non-factor service balance, and investment income and transfer balance.

28. When adjusted for valuation changes, the change in the total debt stock is equal to net borrowing given by this equation. Capital exports can thus be calculated for the historical period. It would not be appropriate to view the derived capital exports figures as only capital flight. Inter alia, it includes errors and omissions of the balance of payments, "legal" capital exports including trade finance, and errors in the estimation of the non dollar debt share. Nevertheless, the capital export variable bears a certain resemblance to patterns of capital flight analyzed in other studies.

29. Investment income payments and receipts are calculated as multiples of estimated payments on the basis of identified stocks of assets and liabilities. This part of DEMOD is almost identical to the debt modules used for the remaining HICs; for further detail, see below, see page $14 \mathrm{ff}$. 
30. This structure - despite its simple form and a number of shortcomings - allows the state of the world macroeconomy to directly influence economic performance of debtor countries. The key variables in this linkage are (i) the US short term interest rate; (ii) OECD output growth; (iii) net flows to debtor countries. The response to variations in these exogenous variables is discussed on pages $18 \mathrm{ff}$.

\section{DEMOD parameter estimation and tracking performance}

\section{(a) Parameter estimation}

31. The data used for the estimation are from OECD sources for historical series of OECD variables, and from the World Bank's World Tables for data on Latin American countries. Some variables had to be assumed or estimated. This is the case of the capital stock: the capital-output ratio was simply assumed to be 3.0 in 1975 . The exponent on capital in the potential output equation is assumed to be 0.4 , combining the assumption of Cobb-Douglas technology, competitive markets and an income distribution assumption; the proportion of non dollar debt in the total was estimated to be between 0.3 and 0.4 ; the ratio of variable to fixed rate debt was estimated on the basis of World Debt Tables data. Data problems were encountered for a number of smaller LAT countries, especially with data availability for 1986 and 1987 . Missing data were estimated on the basis of average ratios. Some ad hoc adjustments were required to trade data. Exchange rates and deflators are used to express all variables in constant US 1980 dollars.

32. The equations were estimated with time series data from 1975 to 1987 . The year 1975 is after the second oil price shock, and is about the time when large scale lending to Latin America started; also, some time series from INTERLINK are not available for earlier years. This gives 13 observations, which is rather few for econometric work, and especially for testing. Behavioral equations of DEMOD were estimated by simple ordinary least squares, using Micro TSP and MICROFIT. In the output block especially, simultaneity is present and leads to biased and inconsistent parameter estimates. In this case, one can improve on OLS by using two-stage least squares which are biased, too, but they are consistent. With a sample of 13 observations, it is not clear - on the basis of large sample theory that much is gained by using consistent estimators, especially since 2SLS estimates have a larger variance than OLS. Nevertheless, "diagnostic" 2 SLS were performed; as a rule, results were almost identical to OLS. With 3SLS, specification errors in one equation would influence the parameter estimates of all other equations in the system. "Diagnostic" 3SLS for Mexico yielded results that were not statistically different from OLS. Within the structural framework laid out above, slightly different functional forms and activity variables were tried.

33. The relatively few observations do not permit an extensive use of diagnostic statistics. In the first stage, the DW statistic was used as an indicator of functional misspecification and serial correlation. In a second stage, a number of equations were subjected to more rigorous testing, 


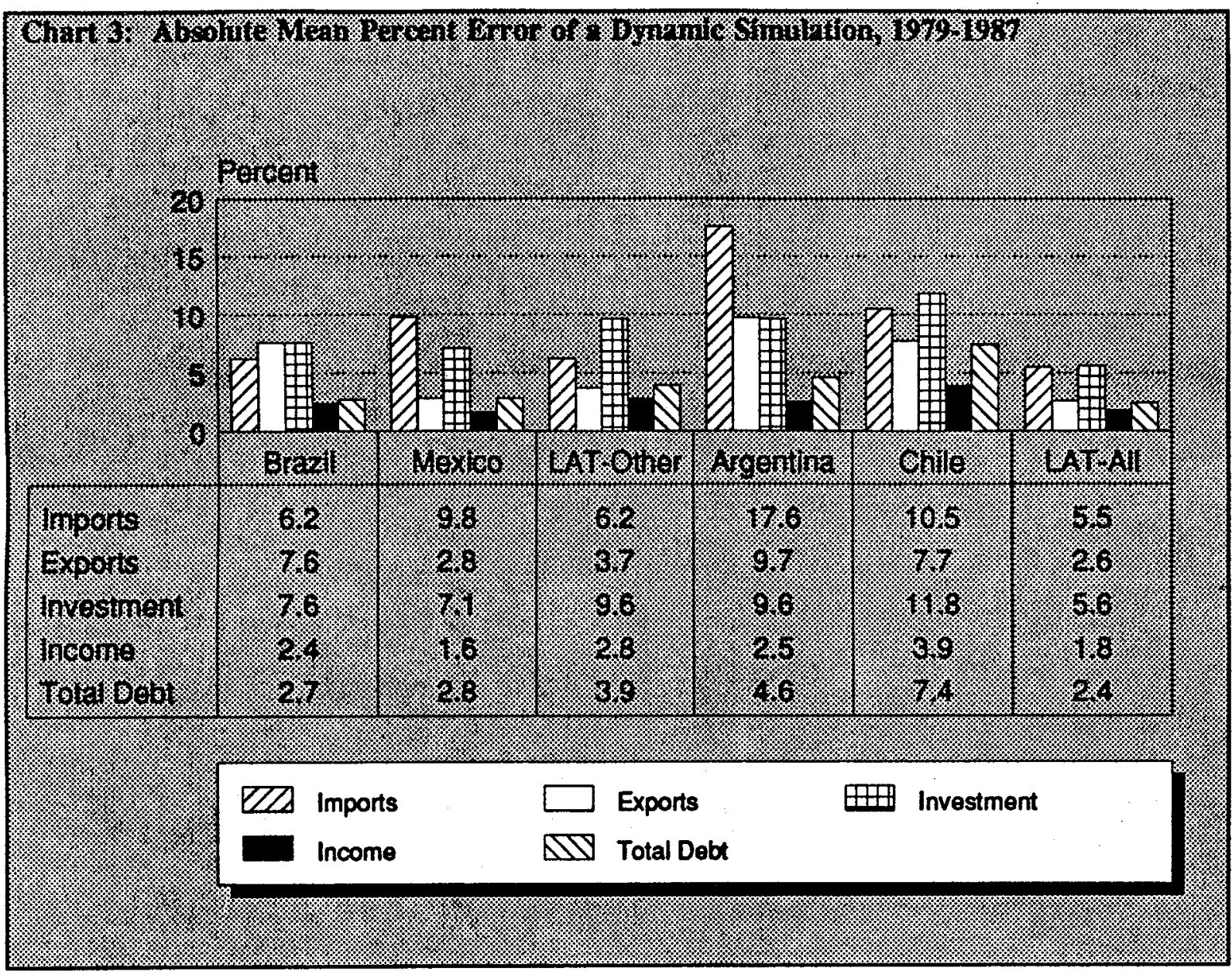

including for heteroskedasticity and misspecification of functional form. CUSUM and CUSUMSQ plots were used to check for structural breaks. Detailed regression results are reported in the appendix. Final selection of an equation was made on the basis of its simulation properties with the RMS error as selection criterion.

34. The equation for the long term interest rate, INTLT (see also page 15 where the HIC debt modules are described), was fitted by a manual grid search. The ratio of floating to fixed rate debt, the spread over the short term US interest rate, and the long term interest rate were experimented with to arrive at a reasonable fit with actual interest payments. No attempt was made to fine-tune the fit. A complete listing of the models for Argentina, Brazil, Chile, Mexico, and LAT-other is in the appendix. The appendix also contains a complete list of exogenous and endogenous variables, explanation of acronyms, and sources of data with concordance to the World Tables.

\section{(b) Tracking behavior}

35. While the statistical results for individual equations are of interest, the complete models are equally importantly evaluated by their simulation and tracking properties. Of such a simple model as 


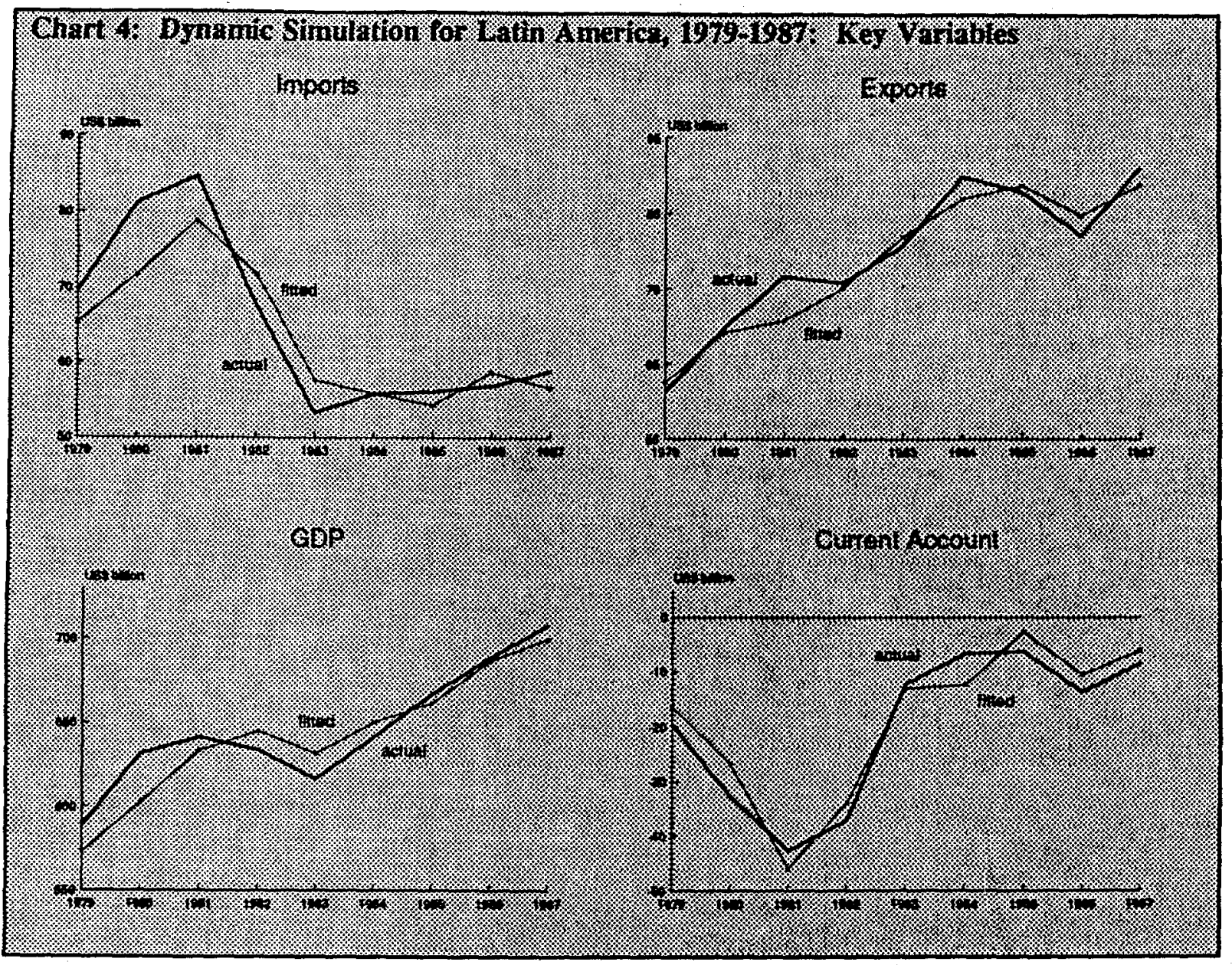

DEMOD, one would not expect great forecasting accuracy; but it is important that the model track satisfactorily the pattem exhibited by the data, including turning points. To check this, dynamic simulations were carried out over a nine year period from 1979 to 1987 . Generally, tracking performance appears satisfactory. The model is stable; residuals are not unreasonable for this kind of model; and turning points are well traced. Chart 3 shows absolute mean per cent errors for a dynamic simulation from 1979 to 1987 for key variables. Simulation errors for Brazil, Mexico, and LAT-Other, which account for most of Latin America, appear reasonable; the models for Argentina and Chile are less satisfactory. The Latin America region taken as a whole has smaller simulation errors than any of the individual country models, of the order of five per cent or less.

36. Error statistics alone do not describe a simulation model very well, since one of the more important criteria is how well turning points are traced. Actual versus predicted values for some variables for the Latin America region are graphed in Chart 4. Tuming points are reasonably well identified. DEMOD captures correctly the downtum in investment, income, and imports in 1981-83; it traces the decrease in exports during 1985/86 and the following upturn in 1987. Overall, while some residuals are large, and would render use as a forecasting tool difficult, the model structure DEMOD imposes on the data seems quite capable of reproducing the historical pattern of key variables. 
37. For the analysis of debt related questions, it is important that the model be able to simulate the stock of debt reasonably well; because the compound interest effects tends to increase small errors over time. The actual versus the predicted path of debt is shown in ?. Debt is simulated fairly well, which can partly be attributed to the use of exogenous capital export variable. With the knowledge of this variable, and a decent simulation for the current account, one would expect good tracking for the debt stock. Underestimation of capital exports was one reason for the unsatisfactory debt projections produced in the early eighties.

\section{(c) The baseline for simulations}

38. For scenario analysis in the medium term future, a baseline is needed. The broad features of the baseline that form the basis for the simulations can be described as follows. Growth in the OECD arca is smooth, and projected at 2.9 per cent between 1990 and 1994 - the same as during the eighties. Capacity utilization in the OECD area remains at high levels, but inflation peaks in 1990 and declines thereafter to 3.6 in 1994. This development is mirrored by the short term interest rate, which peaks at $9.2 \%$ in 1990 and thereafter declines to $7.6 \%$ in 1994 . The trilaterial current imbalances between the United States, Japan, and Germany remain roughly constant, and some additional imbalances develop within Europe. Thus there is little adjustment, but there is also no crisis. The assumption is that these imbalances can be smoothly financed, without major changes in exchange rates or interest rates.

39. Based on this external environment, baselines for Argentina, Brazil, Chile, Mexico, and LATOther have been constructed. These DEMOD baselines take a cautiously optimistic view of the world. To the generally favourable external environment, slowly increasing net flows and low capital exports are added. This assumes that Latin American countries make some progress with macro-economic stabilization as well as structural reforms. Latin America's current account deficit remains at about $\$ 10$ billion, which seems able to be financed. Taken together with satisfactory export growth, this would appear to allow growth to resume. Most DEMOD baseline figures have been projected by using the model itself. Output growth has been checked for consistency with Project LINK and World Bank projections, and achieved mainly through add factors in the investment equations. Key variables are shown in Table 1. Output growth for Latin America is assumed to be 4.1 per cent per annum. Imports grow at 9.6 per cent, which implies an import elasticity of 2.3. Relatively rapid export and GDP growth improve debt indicators over time, though not dramatically. Total debt is projected to increase by $\$ 90$ billion to almost $\$ 500$ billion by 1994 .

40. It should be pointed out that this scenario could be considered optimistic on two counts. First, there are risks in the baseline for OECD countries. Current account imbalances may not prove as sustainable as assumed therein; sudden adjustment could involve much reduced OECD growth and possibly higher US interest rates. Such a development would cloud considerably the outlook for Latin America. Second, macroeconomic policies in Latin America may not improve very much, and reform efforts under way could be derailed easily by political developments. In such a case, much higher 
Table 1

DEMOD: The Baseline for Latin America

\begin{tabular}{|c|c|c|c|c|c|c|}
\hline & Brazil & Mexico & LAT-Other & Argentina & Chile & Total \\
\hline Output Growth (Annual Average 89-94) & 4.7 & 4.1 & 3.5 & 1.1 & 5.2 & $4: 1$ \\
\hline Goods Import Growth (Annual Average 89-94) & 11.5 & 12.4 & 4.0 & 12.3 & 7.8 & 9.6 \\
\hline Goods Export Growth (Annual Average 89-94) & 6.3 & 6.8 & 4.6 & 6.4 & 8.9 & 6.3 \\
\hline Current Account (Average 89-94, \$ bn) & 2.8 & -3.7 & -7.7 & -1.3 & -0.9 & -10.0 \\
\hline Total Debt $(89 / 94, \$$ bn) & $112 / 112$ & $103 / 125$ & $100 / 141$ & $59 / 77$ & $25 / 32$ & $398 / 488$ \\
\hline Debt to GDP Ratio (89/94) & $26 / 16$ & $62 / 48$ & $66 / 61$ & $75 / 73$ & $101 / 79$ & $46 / 37$ \\
\hline Debt to Export Ratio (89/94) & $315 / 191$ & $293 / 202$ & $299 / 273$ & $417 / 323$ & $297 / 206$ & $315 / 231$ \\
\hline
\end{tabular}

capital exports, and lower investment and growth could be expected. The baseline may be best viewed as a fair weather scenario, particularly from the point of view of domestic policies in debtor countries.

\section{The HIC debt models}

41. While the main modelling effort has been concentrated on the major Latin American debtors, simple debt accounting models have been constructed for each of the 17 Highly Indebted Countries (HICs) (see Appendix E. for a list of the HICs). Equations are provided linking the main balance of payments flows for each of these countries to INTERLINK simulations so that the impact of various scenarios on the evolution of total debt and debt servicing can be traced for the HICs as a whole. Unlike the main DEMOD models, these debt accounting models provide no feed-back to INTERLINK.

\section{Linkage to INTERLINK}

42. The HIC models take no account of the likely diversity of response of individual HICs to external shocks; only debt interest payments are given country-by-country treatment. Each HIC belongs to one or other of the regional groupings which INTERLINK uses to represent non-OECD countries (see Appendix E.). Simple equations link each of exports and imports of goods and services to the corresponding regional total; deviations from baseline are allocated to individual countrics using baseline proportions, thus for exports of goods and (non-factor) services in country $i$ in region $R$ :

$$
\begin{aligned}
& x G S_{1}=a_{1} * X G S_{R} \\
& \text { with } a_{1}=X G S_{1} \text { (baseline) } / X G S_{R} \text { (baseline) }
\end{aligned}
$$

where $\mathrm{XGS}_{\mathrm{R}}$ is exports of goods and services for the relevant region in a particular INTERLINK simulation; $a_{i}$ will of course vary through time though fixed in simulation. A similar equation is used for imports of goods and services. 
43. Other items in the current account are transfers, which are taken as exogenous, and credits and debits on factor services. Credits on this item are not very important for most HICs; a simplifying assumption is used: all credits are assumed to be interest payments on reserves which are assumed to be held in dollars and to earn interest at a rate of interest directly proportional to LIBOR. Hence

$$
\mathrm{XSI}_{\mathrm{i}}=\mathrm{IRSUS}^{*} \mathrm{XSI}_{\mathrm{i}} \text { (baseline) } / \text { IRSUS (baseline) }
$$

where IRSUS is the US short term interest rate. The spread between this interest rate and LIBOR is assumed to be constant.

\section{Interest Debits}

44. The structure of the equations for debt interest flows described here is also used in DEMOD. Debits on factor services consist mainly of interest payments on foreign debt. Two equations are used to model this item. One takes World Bank data on payments of interest on long term debt and models this in terms of the stock of long term debt and United States treasury bill rate. A second equation uses an implicit equation for interest payments on short-term debt (for which explicit data are not available) and, taking this together with payments on long-term debt, models factor services debits.

The resulting equations are of the following form for all countries:

$$
\begin{aligned}
& \text { IIDEBL }=\text { LTD * }(\text { SFX*RFX }+(1-S F X) * D D * I R S U S / 100\} \\
& \text { IIDEBS }=\text { STD * }(\text { IRSUS }+ \text { MK }) / 100 \\
& M S I=E A *\{\text { EE*IIDEBL }+(2-E E) * \text { IIDEBS }\}+\text { AD }
\end{aligned}
$$

where: IIDEBL,IIDEBS

LTD,STD

SFX

IRSUS

MSI

RFX

DD,MK,EA,EE,AD interest payments on long and short debt respectively stock of long and short debt, respectively share of fixed interest rate debt United States treasury bill rate Factor income debits rate of interest on fixed rate debt coefficients

\section{Estimation}

45. DD, MK, EA, EE and AD are all coefficients to be estimated. For each country their cstimated values are tabulated in Appendix E. RFX was set to a constant 6 per cent in almost all 
cases, corresponding to OECD estimates of the average interest rate paid on fixed interest debt for all developing countries, which have shown very little variation outside a range close to 6 per cent over the whole period since 1975 .

46. The data on long-term interest are on a payments basis whereas the current account item for debits on factor services (denoted MSI) is measured on an accruals basis. Hence, if the model for interest payments fitted the data exactly, the model for MSI would fit badly during periods when arrears are being accumulated or paid off. Since the focus here is not on modelling payments but on accruals we did not attempt to produce well-fitting equations for payments; rather cquations that satisfy some a priori conditions and produced a "reasonable" fit were produced for long term interest payments (denoted IIDEBL), and the predictions from these equations were then used to model MSI. In both cases the functional form was over-parameterised (more coefficients than variables) to allow flexibility, and coefficients were estimated by grid-search and graph-plotting rather than by regression.

47. Equation (3) was estimated directly but equation (4) was estimated indirectly by substituting for IIDEBS in equation (5); equation (5) itself was estimated using fitted values for IIDEBL on the right-hand side, not actual values. Fitted rather than actual values for interest payments on long term debt were taken to be a more accurate representation of accruals than data on actual payments would be. It may be noted that the final result is to produce an equation for MSI which is a complicated function of IRSUS and the stock of debt; three equations are probably not necessary for this. However, a priori there is no good reason why such an approach suffices for MSI (which may contain other flows than pure debt interest); estimating initially equation (3), where it is known that the data for stocks and flows match exactly (with the sole exception of the difference between payments and accruals) is a useful check of the plausibility of the specification.

48. To complete the modelling of the balance of payments and debt consequences of an extemal shock on each HIC, a pair of equations for updating the debt stocks is added. Data on both short-term and long-term debt is required. In simulations it is assumed that variations in the current balance from baseline will be entirely financed through changes in debt, and not through changes in reserves, and that in any given period the proportion of short and long-term debt will remain as in the baseline. Data were available for all variables up to 1987 ; some estimates were used for 1988 and values for 1989

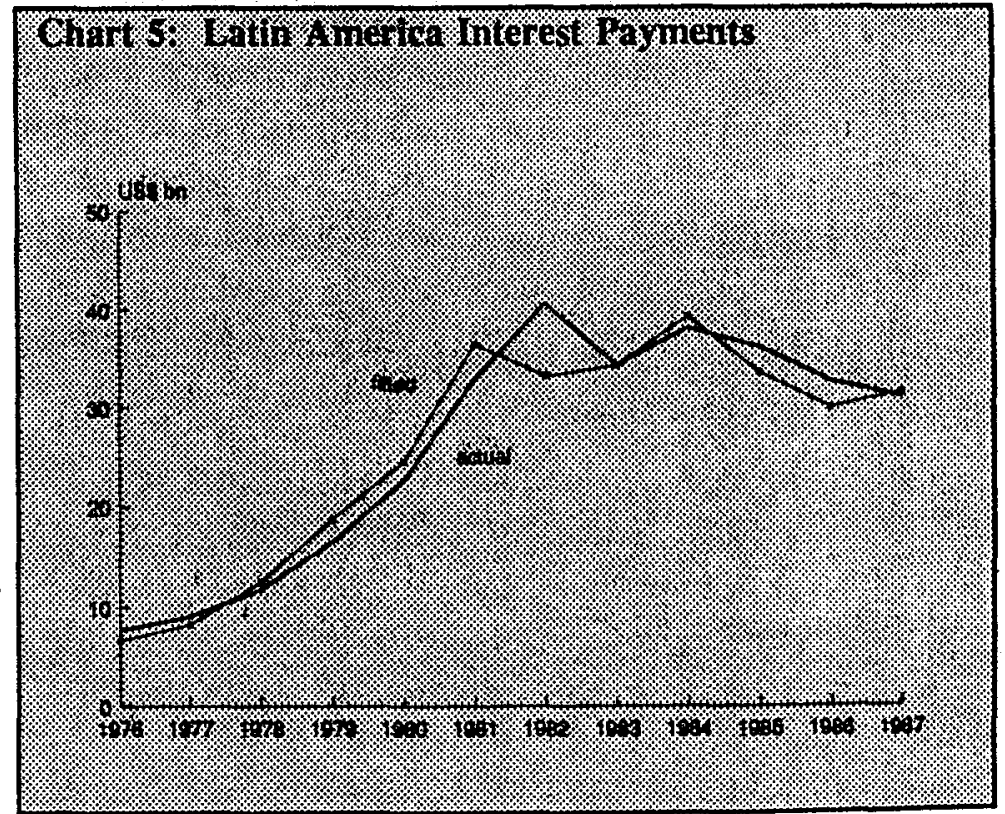


onwards were calculated by applying the above equations to the baseline, with all share-type variables fixed at their 1988 lcvels. Unlike in the DEMOD models, there is no account taken of valuation effects resulting from exchange rate movements ${ }^{11}$.

\section{Tracking performance of the investment income equations}

49. In many cases the naive modelling approach used worked well. In particular the shift variables used (DD EA and AD) rarely needed to be substantially different from unity (for DD and EA) or zero

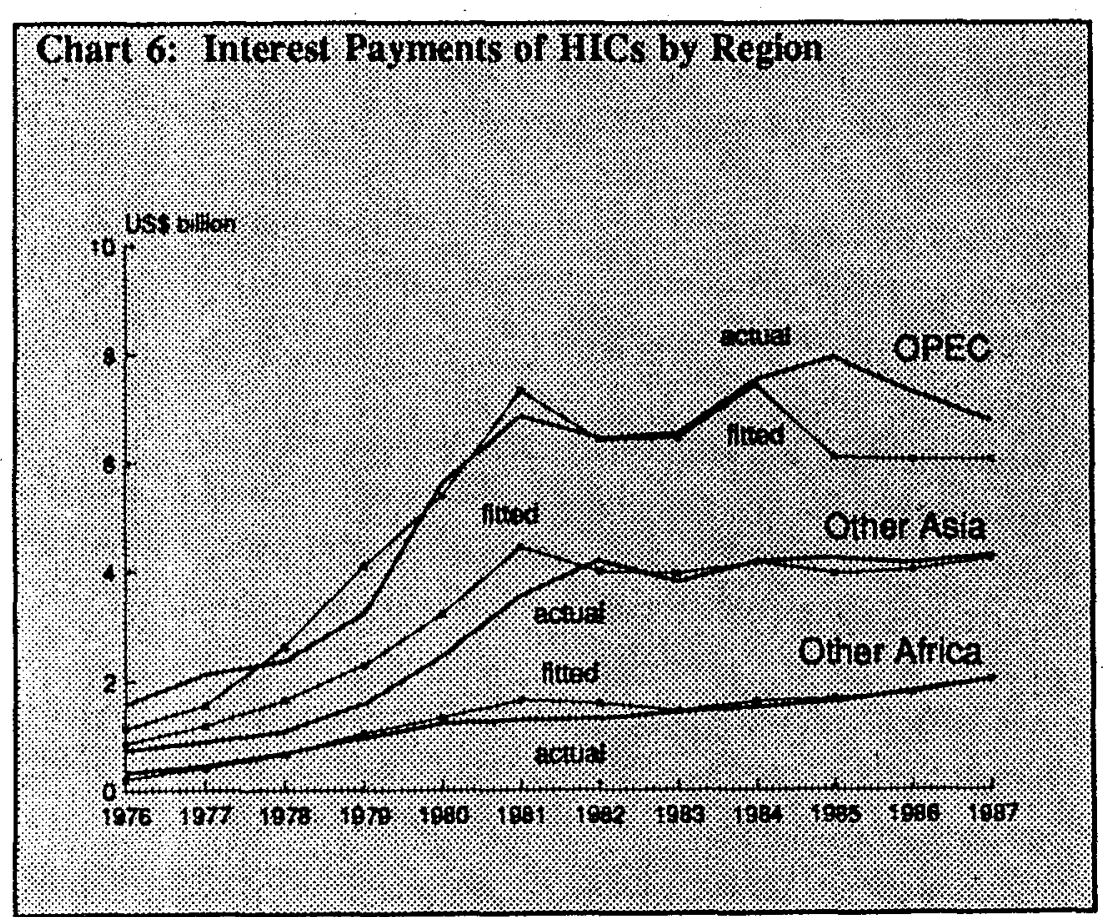

(for AD). In some cases high values were used for EE in equation (5), implying an exaggerated weight for long-term debt interest in factor payments, and some values of MK are not very plausible estimates of borrowing margins over LIBOR for the countries concerned. Certain countries produced rather badly fitting models (in particular those for Ecuador, Bolivia and Yugoslavia). But on the whole the tracking performance for MSI is very respectable. Following successful estimation for

HICs this type of formulation for MSI was incorporated into the DEMOD structure.

50. The main systematic error across countries is that the models tend to predict that the peak in the average interest rate occur in 1980, when US short term rates peaked, rather than in 1981, when the average apparent interest rate (calculated by dividing factor debits by total debt) peaked. Given that this was the only obvious error of timing, and that the model tracked very well the rising factor payments trend of the 1975-1979 period, no attempt was made to experiment with more refined specifications. Chart 5 and Chart 6 show fitted and actual values of MSI for HICs grouped according to which INTERLINK region they belong. 


\section{SIMULATION PROPERTIES}

51. An important performance criterion of a model is its reaction to shocks. A model may have small residuals and track historical data, especially within the sample, reasonably well, but may have implausible marginal properties. In this section, the results of standard shocks on DEMOD are reported. All simulations have been done in combined mode with INTERLINK. The results of the simulations therefore incorporate the direct impact of, e.g., an increase in the US short term interest rate, as well as the indirect effect through slower GDP growth in the OECD area and lower raw materials prices, etc. Exchange rates are exogenous; OECD govermment consumption and investment are constant in real terms. The shocks are:

(i) The US short term interest rate is increased by one percentage point. This increases interest payments and tends to worsen the current account. At the same time, however, it reduces net real lending, which reduces domestic output growth and tends to reduce imports.

(ii) OECD GDP is increased by one per cent over baseline. This increases demand for Latin American imports and hence tends to improve the current account and increase growth. OECD short term nominal interest rates are held constant.

(iii) Real net flows is increased by $10 \%$ of baseline imports. This increases investment and growth, and leads to higher imports. The negative effect on the current account is somewhat softened by the feedback effect from the OECD area: increased import demand from Latin America increases OECD growth and hence demand for Latin American products.

Detailed tables for these simulations are in the appendix. The following sections highlight important features of the simulations and present them in simple graphs. It should be noted that these simulations are baseline-dependent. If the shocks were introduced in different years, DEMOD would show slightly different changes. This is due to the stocks that are in the model: capital and debt. Measures and flows derived from these stocks will obviously differ if these stocks differ, as they do between different years.

\section{A. Increase of the short term interest rate}

52. An increase of one percentage point of the US short term interest rate increases Latin American factor service payments by 4.9 billion dollars. The current account worsens by less, however, because higher interest payments translate into reduced foreign finance for investment, leading to lower investment and GDP and hence to lower import demand. The current account deterioration is $\$ 3.4$ billion in 1990 , increasing to $\$ 10.7$ billion after five years due to the compound interest effect. Much of this current account deteriation is due to higher interest payments, but there 
are also indirect effects at work. Most important, higher interest rates in the United States reduce economic activity and hence import demand, leading to export losses for Latin America. The combined effects of the interest rate increase on Latin America's GDP is not negligible. In 1990, GDP is reduced by 0.4 per cent against the baseline; in 1994, GDP is 2.8 per cent lower than in the bascline. Lower GDP, higher debt, and increased interest all tend to worsen indicators of creditworthiness. Chart 7

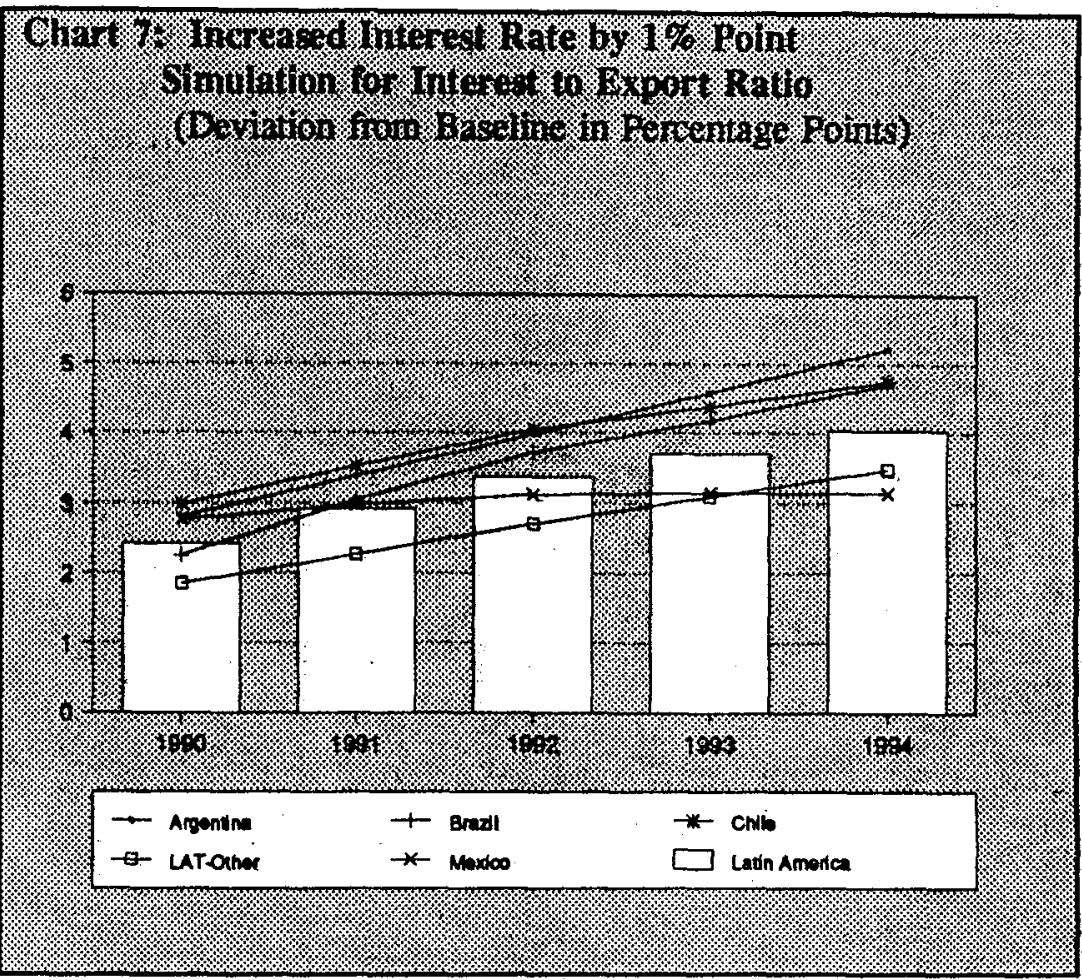
shows the change of the interest to export ratio in percentage points against the baseline. For the Latin America region as a whole, the interest to export ratio increases by 4 percentage points after five years; lowest is Mexico (3.1 percentage points), highest Argentina (5.2 percentage points). Country differences depend on the debt stock, the ratio of floating rate debt, the influence of foreign finance on investment, and the influence of investment on GDP.

\section{B. Increase of OECD GDP by one per cent}

53. An increase in the level of OECD GDP by one per cent increases the market growth variables for Latin America and hence leads to higher exports. The increased OECD GDP has been achieved in this simulation by targetting total domestic demand (TDDV) with private consumption (CPV). Monetary policy in OECD countries is assumed to accomodate the increase of consumption; OECD short term interest rates remain constant. As a result of increased exports, the Latin American current account improves by $\$ 2$ billion in the first year. By 1994, partly due to the compound interest effect, the improvement in the current account has increased to $\$ 6$ billion. The simulated change of the interest to export ratio from baseline in percentage points is shown in Chart 8 . The ratio improves for Latin America by 0.7 percentage points in 1990 increasing to 1.5 percentage points in 1994. This is due to a combination of three factors. First, increased exports increase GDP directly. Second, higher exports reduce the current account deficit and the stock of debt. Third, lower debt stocks lead to lower 
interest payments after the first year, thereby increasing foreign finance available for investment, leading to higher investment and GDP. Latin America's GDP increases by 1.2 per cent in 1990; by 1994 , the change is 1.8 per cent.

54. Within the Latin America region, there are considerable differences in the reaction to increased OECD GDP. Argentina's GDP does not change, reflecting the absence of exports in Argentina's GDP equation. Brazil and Mexico are best at transforming higher OECD GDP into domestic growth. By 1994, Brazil's GDP has increased by 2.5 per cent over baseline, Mexico's by 1.8 per cent. The figure for LAT-Other is 0.9 per cent.

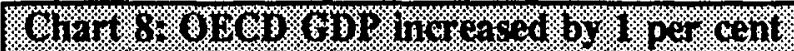

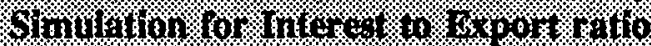

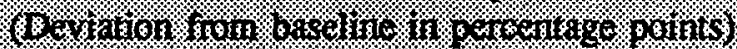

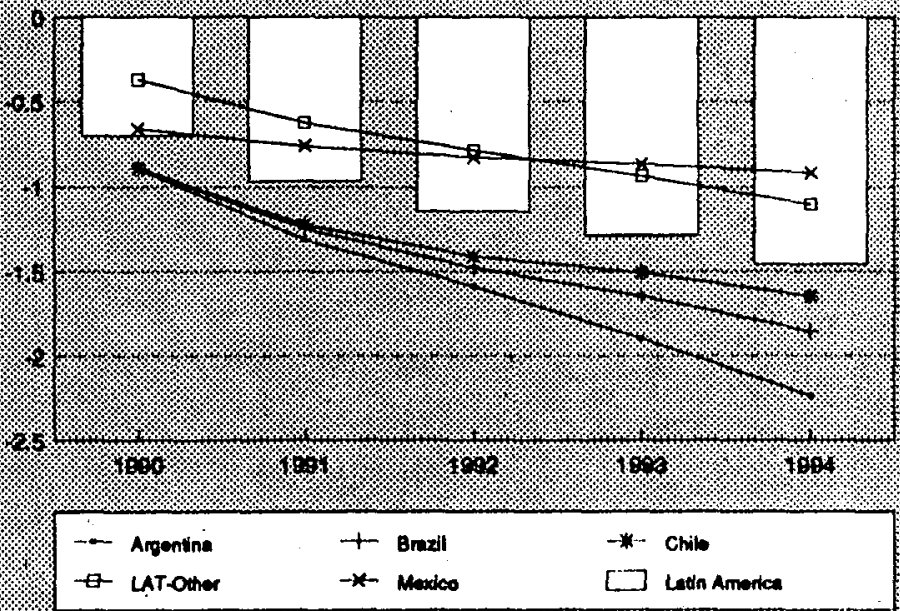

\section{Increase of net flows equivalent to debt reduction of $\mathbf{1 5}$ per cent}

55. Net flows in the simulations are increased by an amount equal to interest savings that would result from a reduction of the debt stock of 15 per cent (assuming that debt is being serviced). This is an interesting simulation. It indicates whether in DEMOD "new money" can be expected to improve the debt situation. New money makes increased investment possible, but it also adds to the debt stock. In DEMOD, new money leads to higher investment and GDP; increased domestic absorption leads to higher imports, worsening the current account. As a result, debt accumulates faster than before, an effect strengthened over time by the compound interest effect. The change of Latin America's GDP from baseline is modest. Chile shows the largest deviation from baseline: its GDP increases by 1.2 per cent over baseline. At the other end of the spectrum are Argentina and Brazil. The DEMOD country model for Argentina describes it as generally inefficient at transforming forcign finance into investment. Argentina's GDP increases by 0.3 per cent, Brazil's by 0.5 per cent after five years. This corresponds to a change in the growth rate of less than 0.1 per cent per annum. 
56. While the impact on growth is small, indicators of creditworthiness deteriorate. The current account deficit increases by $\$ 5$ billion over five years. The interest to cxport ratio of Latin Amcrica increases by 0.5 percentage points over bascline by 1994 , as shown in Chart 9. New money thus leads to a worsening debt situation, although it does increasc GDP growth.

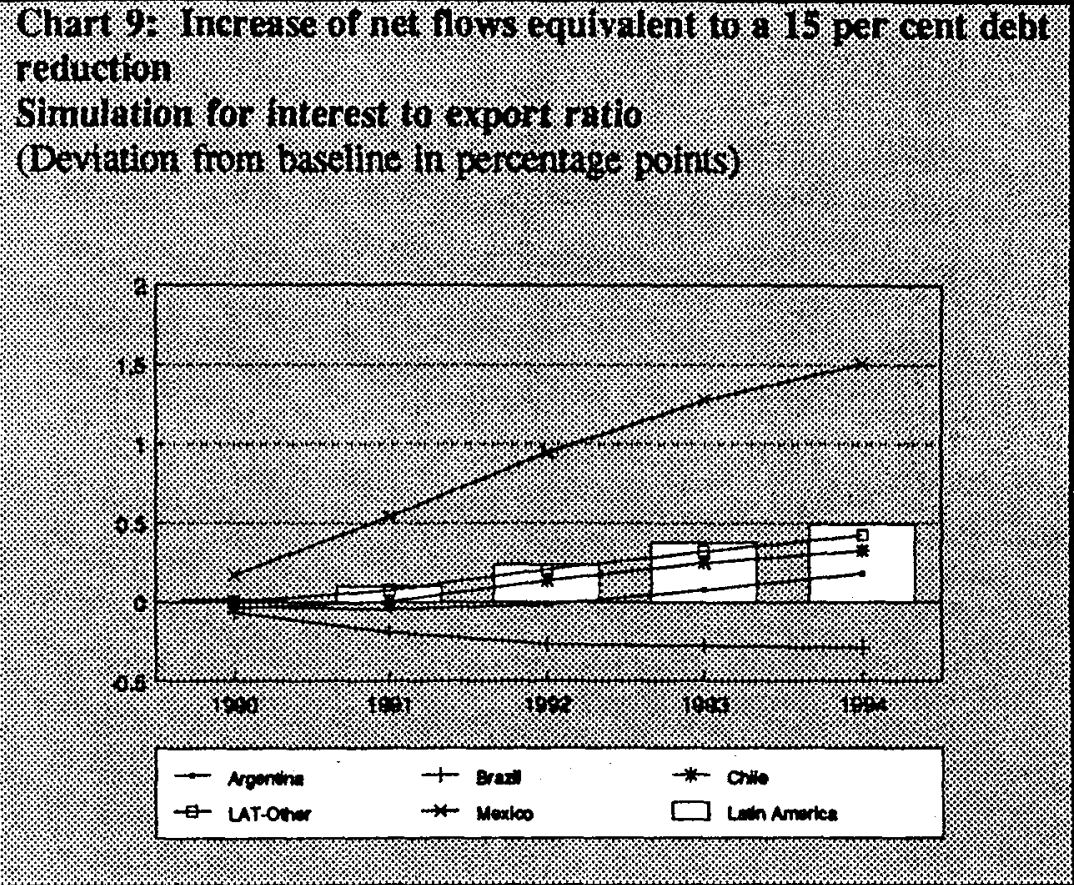

E. Impact of the simulations on the HICs

57. The prececding paragraphs have shown the reaction to standard shocks of key variables of the Latin America region. Based on the joint runs of INTERLINK and DEMOD, the HIC models calculate the changes from baseline of the interest to export ratio for the 17 highly indebted middle income countries. These changes

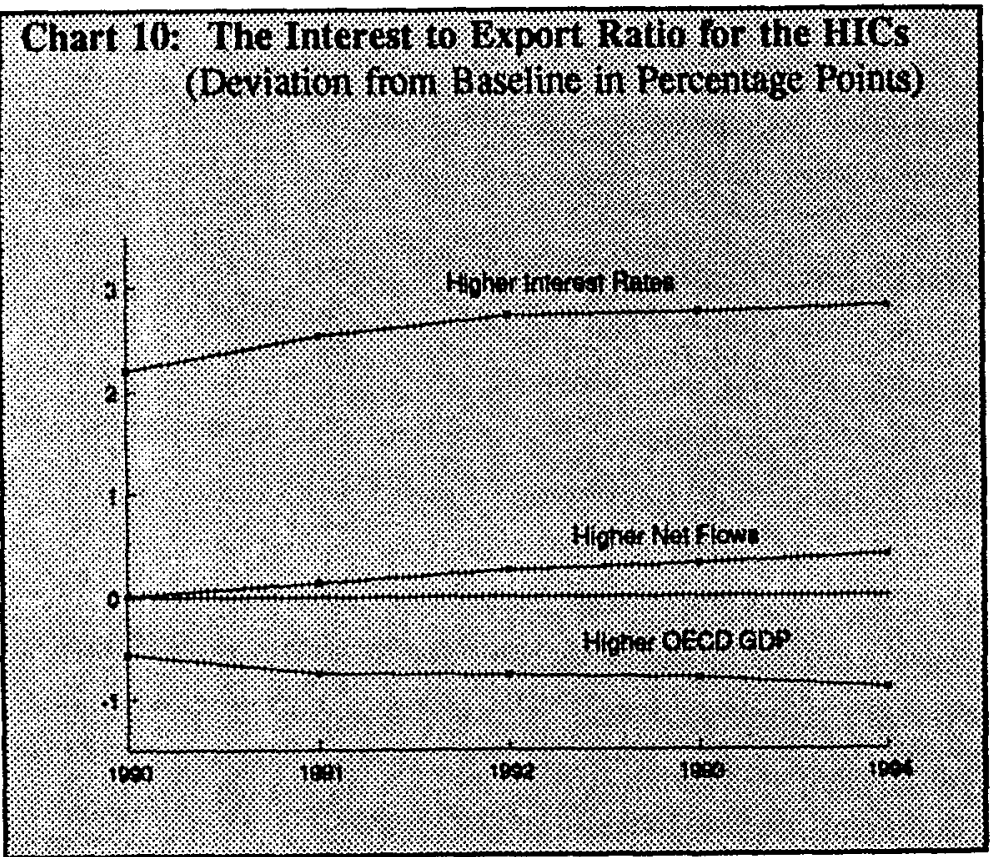
are graphed in Chart 10 . Of particular interest is the comparison of changes in the interest to export ratio for HICs with the corresponding changes for the Latin America region (see Appendix D). The changes for the Latin America region and for the HICs are rather similar. 


\section{F. The importance of feedback from Latin America for OECD economies}

58. DEMOD and the HIC accounting models have been developed for analyzing the interaction between OECD economic policies and the debt situation of Latin America and of highly indebted middle-income countries. It is also interesting to analyze the strength of the feedback loop between

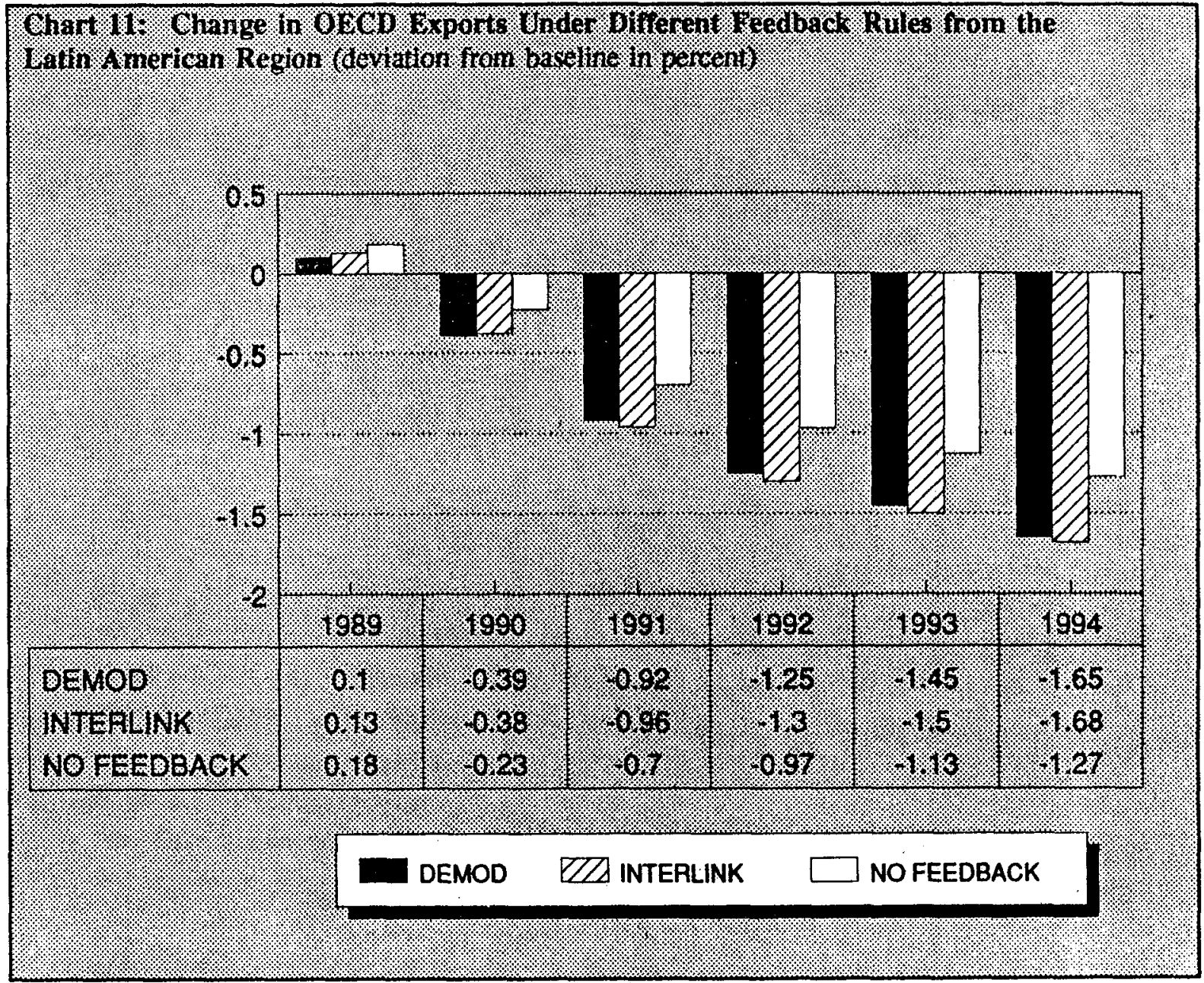

the OECD area and Latin America. This is possible since DEMOD is designed to be able to replace the INTERLINK Latin America region. Such an exercise can provide some quantitative insight into how important Latin America is to the OECD economies. A comparison between the feedback loop of INTERLINK and of DEMOD can give some indication of the possible value of modelling nonOECD areas in more detail than is done in the current version of INTERLINK.

59. For a quantitative assessment of the importance of feedback from Latin America for OECD economies, the simulation with an increase in the US short term interest rate of one percentage point has been taken as an example (see page 18f.). Three variants of this simulation are presented below. First, INTERLINK and DEMOD are run in combined mode; the DEMOD models replace the equation for Latin America. In this variant, increased interest rates and lower demand for Latin Amcrican exports from the OECD area lead to lower GDP growth in Latin America; as a result, Latin American 
import demand is reduced, which is then fed back to the OECD economies. Second, INTERLINK is run "as is": Latin America is represented by a finance-constrained import demand equation. Higher interest ratcs reduce available financing and hence Latin American import demand. Third, Latin Amcrican import demand is exogenized and kept at baseline levels. Thus, there is no feedback from the Latin American region to OECD economies. The deviation of OECD exports of goods and services under different feedback rules from Latin America is shown in Chart 11.

60. Two points are noteworthy in this comparison. First, the feedback from the Latin American region matters. In 1994, five years after the increase of the US short term interest rate by one percentage point, OECD exports are reduced by 1.27 per cent in the simulation without feedback; this contrasts with a reduction of OECD exports by 1.68 per cent for the feedback from the INTERLINK import cquation for Latin America, This is not an insignificant difference. If the reduced demand from Latin America is not taken into account, the magnitude of the effect on OECD exports is understated by as much as one quarter.

61. Second, the feedback between the INTERLINK import equation for Latin America and the more detailcd DEMOD models is similar. The differential impact of these two feedback rules on OECD cxports is 0.05 percentage points or less; the differential impact on the OECD current account is $\$ 0.8$ billion or less.

62. Two preliminary conclusions may be drawn from these simulations. First, the feedback from Latin Amcrica to the OECD area makes a significan difference to economic aggregates of the OECD economies. Second, it would appear that the modelling of Latin American imports in INTERLINK as being finance constrained is appropriate for a macroeconomic model that focuses on the OECD area. Despite its simplicity, this approach gives very similar anwers to the more detailed modelling of Latin America in DEMOD. 


\section{NOTES}

1. Cline (1983) is probably the best-known example of this type of modelling approach to analyse the debt crisis.

2. A description of INTERLINK and its simulation properties can be found in Pete Richardsion (1988). See O'Brien, Meuro and Camilleri (1989) for details on the non-OECD regional aggregates used by Interlink.

3. DEMOD builds on earlier work on debt models carried out at the OECD. Sec Saunders and Dean (1986).

4. "LAT" is the mnemonic in Interlink used to identify the Latin American region, which excludes, as mentioned above, Venezuela, which INTERLINK treats as part of a group of OPEC members. Venzuela is included in the list of HICs for which debt accounting models have been developed.

5. Bolivia, Colombia, Costa Rica, Dominican Republic, San Salvador, Guatcmala, Haiti, Honduras, Jamaica, Nicaragua, Panama, Paraguay, Peru, Trinidad \& Tobago, Uruguay. Excludéd duc to data problems have been Barbados, Guyana, Antigua \& Bermudas, Belize, Dominica, St. Kitts and Nevis, St. Lucie, St. Vincent \& Grenadins, Surinam, Bahamas, Grenada. The excluded countries account for less than $5 \%$ of relevant economic aggregates of Latin America.

6. In the case of Argentina, 0.6 has been used. By using .4, changes in potential output would have been small compared to the large output changes that actually occurred. To attribute these large output changes only to changes in actual output appeared not very plausible (Another possibility would have been to allow for faster depreciation due to insufficient maintenance).

7. Recently, Srinivasan and Vines (1990) have built a macroeconomic model for Latin Amcrica that has fiscal and monetary policy instruments. Many resources were necessary to build an analytical database for Latin America.

8. Other analysts have found the use of a proxy for government policy useful. Kormendi and McGuire (1985) find that the rate of inflation is negatively correlated with GDP growth in a sample of 46 countries.

9. In practice, constraints are often "on/off" rather than "soft." Regime switching models might therefore be more appropriate. In this context, with only 13 annual observations to play with, such modelling would be over-ambitious.

10. In some equations, usually rather badly-fitting ones, capacity utilisation appears with a positive sign. Further estimation work must address this counter-intuitive result.

11. In this exercise, no attempt was made to take into account either already-agreed or possible debt reduction agreements reached between HICs and creditor banks or governments. 


\section{BIBLIOGRAPHY}

Kormendi and McGuire (1985), "Macroeconomic determinants of growth: cross country evidence", Joumal of Monetary Economics, 16, 141-163.

O'Brien, P., Meuro, L. and A. Camilleri (1989) "Revised groupings for non-OECD countries in OECD's macroeconomic model Interlink" OECD Working Paper no. 64.

Saunders, P. and A. Dean (1986), "The international debt situation and linkages between developing countries and the OECD", OECD Economic Studies, 7, 155-203.

Richardson, P. (1988), "The structure and simulation properties of OECD's INTERLINK model", OECD Economic Studies, 10, 57-122.

Cline, W.R. (1983), International debt and the stability of the world economy, Washington, D.C.

Srinivasan, T.G. and D. Vines (1990), "Simulations of an econometric model of Latin America", Paper presented to a Brookings/PUC-Rio/CEPR workshop held in Rio de Janeiro, 29-31 October 1990. 


\section{APPENDIX}

\section{Appendix A: Glossary of Acronyms}

\section{Glossary of Calculated Series}

$\begin{array}{ll}\text { Imports } & \\ \text { MEDV } & \text { Energy import volume } \\ \text { MMDV } & \text { Manufacture import volume } \\ \text { MRDV } & \text { Raw materials imports volume } \\ \text { MSNIV } & \text { Non-factor service income volume } \\ \text { MGV } & \text { Goods imports volume } \\ \text { MG } & \text { Goods imports value \$ } \\ \text { MGS } & \text { Imports of goods and non-factor services, value, \$ } \\ \text { PMG } & \text { Import unit value of goods } \\ & \\ \text { Exports } & \\ \text { XMDV } & \text { Manufactures export volume } \\ \text { XRDV } & \text { Raw materials export volume } \\ \text { XEDV } & \text { Energy export volume } \\ \text { XSNIV } & \text { Non-factor services export volume } \\ \text { XGV } & \text { Export of goods volume } \\ \text { XG } & \text { Export of goods, value, \$ } \\ \text { XGS } & \text { Export of goods and non-factor services, value, \$ } \\ \text { PXG } & \text { Export unit value of goods } \\ & \\ \text { InCome } & \\ \text { INFL } & \text { Inflation rate } \\ \text { GDIVD } & \text { Gross domestic investment, volume, \$ terms } \\ \text { GDPVD } & \text { Gross domestic product, volume, \$ terms } \\ \text { KKD } & \text { Capital stock in constant \$ } \\ \text { GDPVDP } & \text { Potential GDP in constant \$ } \\ \text { DIFGDP } & \text { Actual minus potential GDP, constant \$ } \\ \text { GDSVD } & \text { Gross domestic savings in constant \$ } \\ \text { RTRANS } & \text { Real net long term lending } \\ & \\ \text { Debt } & \\ \text { CHEXUS } & \text { Rate of change of \$ effective exchange rate } \\ \text { RATDEB } & \text { Ratio of non- \$ debt } \\ \text { TBD } & \text { Trade balance, \$ value } \\ \text { CBNI } & \text { Non-interest current account in \$ } \\ \text { CBD } & \text { Current account, \$ } \\ \text { NBORR } & \text { Net borrowing requirements in \$ } \\ \text { DOD } & \text { Total debt outstanding and disbursed } \\ \text { IIDEBL } & \text { Interest payments on long term debt } \\ \text { IIDEBS } & \text { Interest payments on short term debt } \\ \text { DE } & \text { Debt to export ratio } \\ \text { DG } & \text { Debt to GDP ratio } \\ \text { IE } & \text { Interest to export ratio } \\ \text { NBG } & \text { Net borrowing to GDP ratio } \\ & \end{array}$




\title{
2. Glossary of Input Variables
}

\begin{tabular}{ll} 
Acronym & \multicolumn{1}{c}{ Explanation } \\
INTERLINK & \\
IRSUS & Short term US interest rate \\
EXCHUS & Effective US exchange rate \\
PMRD & Import price of raw materials $(1980=100)$ \\
PMM & Import price of manufactures \\
PMFD & Import price of food \\
PMED & Import price of energy \\
PMS & Import price of services \\
PXRD & Export price of raw materials $(1980=100)$ \\
PXM & Export price of manufactures \\
PXFD & Export price of food \\
PXED & Export price of energy \\
PXS & Export price of services \\
XRVMKT & Market growth of raw material \\
XFVMKT & Market growth of food \\
XMVMKT & Market growth of manufactures \\
XEVMKT & Market growth of energy \\
XSVMKT & Market growth of services
\end{tabular}

$\begin{array}{ll}\text { World Tables } & \\ \text { DEFUS } & \text { GDP deflator for US } \\ \text { MRD } & \text { \$ imports of non-fuel primary products } \\ \text { MMD } & \text { \$ imports of manufactures } \\ \text { MED } & \text { \$ imports of energy } \\ \text { MSNI } & \text { \$ imports of non-factor services } \\ \text { MSI } & \text { \$ factor service payments } \\ \text { XRD } & \text { \$ exports of non-fuel primary products } \\ \text { XMD } & \text { \$ exports of manufactures } \\ \text { XED } & \text { \$ exports of energy } \\ \text { XSNI } & \text { \$ exports of non-factor services } \\ \text { XSI } & \text { \$ factor service payments } \\ \text { GDIV } & \text { Gross domestic investment in 1980 prices } \\ \text { GDPV } & \text { Gross domestic product in 1980 prices } \\ \text { GDPDEF } & \text { GDP deflator } \\ \text { PCV } & \text { Private Consumption in 1980 prices } \\ \text { GCV } & \text { Government Consumption in 1980 prices } \\ \text { LTINT } & \text { Long-term interest payments per DRS } \\ \text { LTAMOR } & \text { Amortization payments on long term debt } \\ \text { LTDIS } & \text { Disbursements of long term debt } \\ \text { RES } & \text { International reserves excluding gold } \\ \text { NDFI } & \text { Net direct foreign investment } \\ \text { NTOFF } & \text { Official net transfers } \\ \text { NTPRIV } & \text { Private net transfers } \\ \text { DODPNG } & \text { Private non-guaranteed debt outstanding/disbursed } \\ \text { DODPPG } & \text { Public and publicly guaranteed long term debt } \\ \text { DODST } & \text { Identified short term debt }\end{array}$

\author{
DEFL.GDP \\ CP.IMP.NFP \\ CP.IMP.MAN \\ CP.IMP.FUEL \\ DR.IMP.NFS \\ DR.FCTINC \\ CP.EXP.NFP \\ CP.EXP.MAN \\ CP.EXP.FUEL \\ CR.EXP.NFS \\ CR.FCTINC \\ KP.L.INV.GDI \\ KP.L.GDP.MP \\ DEFL.GDP \\ KP.L.CON.PAV \\ KP.L.CON.GOV \\ BOP.IMP.LTINTRTST \\ LT.CAP.REPYMT \\ LT.CAP.DISBUR \\ INTL.RES.EXGOLD \\ NET.INVEST.DIRECT \\ NET.TRANSF.OFFCAP \\ BOP.NET.CURTRANS \\ PRV.LLOAN \\ PUB.LLOAN \\ SHORT.DEBT
}


IMF Purchases from the IMF

EXRATE Exchange rate

USE.FUND

PR.EXRATE

\section{- Manual input}

RATDEB

RATFOB

Ratio of $\$$ debt in 1975 (typically assumed .6 to .7)

TIME

Ratio of variable to fixed interest debt. From World debt tables.

KKD

Time trend with $\operatorname{TIME}(1967)=1$

KKD

$\operatorname{KKD}(1975)=$ GDPV/EXRATE $(1980)^{\star} 3$

\section{Varlables in Alphabetical Order}

$\begin{array}{ll}\text { CBD } & \text { Current account, \$ } \\ \text { CBNI } & \text { Non-interest current account in \$ } \\ \text { CHEXUS } & \text { Rate of change of \$ effective exchange rate } \\ \text { DE } & \text { Debt to export ratio debt tables. } \\ \text { DEFUS } & \text { GDP deflator for US } \\ \text { DG } & \text { Debt to GDP ratio } \\ \text { DIFGDP } & \text { Actual minus potential GDP, constant \$ } \\ \text { DOD } & \text { Total debt outstanding and disbursed } \\ \text { DODPNG } & \text { Private non-guaranteed debt outstanding/disbursed } \\ \text { DODPPG } & \text { Public and publicly guaranteed long term debt } \\ \text { DODST } & \text { Identified short term debt } \\ \text { EXCHUS } & \text { Effective US exchange rate } \\ \text { EXRATE } & \text { Exchange rate } \\ \text { EX80 } & \text { EXRATE(1980) } \\ \text { GCV } & \text { Government Consumption in 1980 prices } \\ \text { GDIV } & \text { Gross domestic investment in 1980 prices } \\ \text { GDIVD } & \text { Gross domestic investment, volume, \$ terms } \\ \text { GDPDEF } & \text { GDP deflator } \\ \text { GDPV } & \text { Gross domestic product in 1980 prices } \\ \text { GDPVD } & \text { Gross domestic product, volume, \$ terms } \\ \text { GDPVDP } & \text { Potential GDP in constant \$ } \\ \text { GDSVD } & \text { Gross domestic savings in constant \$ } \\ \text { IE } & \text { Interest to export ratio } \\ \text { IIDEBL } & \text { Interest payments on long term debt } \\ \text { IIDEBS } & \text { Interest payments on short term debt } \\ \text { IMF } & \text { Purchases from the IMF } \\ \text { INFL } & \text { Inflation rate } \\ \text { IRSUS } & \text { Short term US interest rate } \\ \text { KKD } & \text { Capital stock in constant \$ } \\ \text { LTAMOR } & \text { Amortization payments on long term debt } \\ \text { LTDIS } & \text { Disbursements of long term debt } \\ \text { LTINT } & \text { Long-term interest payments per DRS } \\ \text { MED } & \text { \$ imports of energy } \\ \text { MEDV } & \text { Energy import volume } \\ \text { MG } & \text { Goods imports value \$ } \\ \text { MGS } & \text { Imports of goods and non-factor services, value, \$ } \\ \text { MGV } & \text { Goods imports volume } \\ \text { MMD } & \text { \$ imports of manufactures } \\ & \end{array}$

DEFL.GDP

PRV.LLOAN

PUB.LLOAN

SHORT.DEBT

PR.EXRATE

KP.L.CON.GOV

KP.L.INV.GDI

DEFL.GDP

KP.L.GDP.MP

USE.FUND

LT.CAP.REPYMT

LT.CAP.DISBUR

BOP.IMP.LTINTRTST

CP.IMP.FUEL

MMD

$\$$ imports of manufactures

CP.IMP.MAN 


\begin{tabular}{|c|c|}
\hline MMDV & Manufacture import volume \\
\hline MRD & $\$$ imports of non-fuel primary products \\
\hline MRDV & Raw materials imports volume \\
\hline MSI & $\$$ factor service payments \\
\hline MSNI & $\$$ imports of non-factor services \\
\hline MSNIV & Non-factor service income volume \\
\hline NBG & Net borrowing to GDP ratio \\
\hline NBORR & Net borrowing requirements in $\$$ \\
\hline NDFI & Net direct foreign investment \\
\hline NTOFF & Official net transfers \\
\hline NTPRIV & Private net transfers \\
\hline PCV & Private Consumption in 1980 prices \\
\hline PMED & Import price of energy \\
\hline PMFD & Import price of food \\
\hline PMG & Import unit value of goods \\
\hline PMM & Import price of manufactures \\
\hline PMRD & Import price of raw materials $(1980=100)$ \\
\hline PMS & Import price of services \\
\hline PXED & Export price of energy \\
\hline PXFD & Export price of food \\
\hline PXG & Export unit value of goods \\
\hline PXM & Export price of manufactures \\
\hline PXRD & Export price of raw materials $(1980=100)$ \\
\hline PXS & Export price of services \\
\hline RATDEB & Ratio of $\$$ debt in 1975 (typically assumed .6 to .7) \\
\hline RATFOB & Ratio of FOB to CIF imports calculated from WT \\
\hline RATVAR & Ratio of variable to fixed interest debt. From World Debt Tables \\
\hline RES & International reserves excluding gold \\
\hline RTRANS & Real net long term lending \\
\hline TBD & Trade balance, $\$$ value \\
\hline TIME & Time trend with $\operatorname{TIME}(1967)=1$ \\
\hline XED & \$ exports of energy \\
\hline XEDV & Energy export volume \\
\hline XEVMKT & Market growth of energy \\
\hline XFVMKT & Market growth of food \\
\hline$X G$ & Export of goods, value, $\$$ \\
\hline XGS & Export of goods and non-factor services, value, $\$$ \\
\hline XGV & Export of goods volume \\
\hline XMD & $\$$ exports of manufactures \\
\hline XMDV & Manufactures export volume \\
\hline XMVMKT & Market growth of manufactures \\
\hline XRD & $\$$ exports of non-fuel primary products \\
\hline XRDV & Raw materials export volume \\
\hline XAVMKT & Market growth of raw material \\
\hline XSI & $\$$ factor service payments \\
\hline XSNI & $\$$ exports of non-factor services \\
\hline XSNIV & Non-factor services export volume \\
\hline XSVMKT & Market growth of services \\
\hline
\end{tabular}

Export of goods and non-factor services, value, $\$$

Export of goods volume

XMDV Manufactures export volume

XMVMKT Market growth of manufactures

\section{XRD}

XRDV 
Appendix B: DEMOD Model LIstings

\section{Argentina}

Imports

MMDV $=-3.244771 D+10+.6327095^{*} G D P V D+.7632478^{*} M M D V(-1)+A D F M M$

$M E D V=-4.8 D+09-56531441^{*} \mathrm{TIME}+6.6 \mathrm{D}+09^{*}(\mathrm{GDPVD} / \mathrm{GDPVDP})+\mathrm{ADFME}$

$M R D V=-3.7 D+09+8.84 D-02 * G D P V D+A D F M R$

MSNIV $=-3.296 \mathrm{D}+10+.466^{*}$ GDPVDP $+1.08 \mathrm{D}+10^{*}$ (GDPVD/GDPVDP)+ADFMSN

$M G V=M E D V+M M D V+M R D V$

$M G=M E D V^{*} P M E D+M M D V * P M M+M R D V *(P M R D / 2+P M F D / 2)$

$M S N I=M S N I V^{*} P M S$

$M G S=M G+M S N I$

$P M G=M G /(M M D V+M E D V+M R D V)$

\section{Exports}

XMDV $=E X P\left(21.285+0.281^{\circ} \mathrm{LOG}(X M V M K T)+2.7^{*} \mathrm{LOG}(\mathrm{REER})\right)+A D F X M$

$X R D V=E X P(22.5185+1.59 * \operatorname{LG}(X F V M K T / 2+X R V M K T / 2))+A D F X R$

$X E D V=-4.004548 D+08+47515375^{*}$ TIME+ADFXE

$X S N I V=E X P\left(21.324+2.309^{*} L O G(X S V M K T)\right)+A D F X S N$

$X G V=X M D V+X R D V+X E D V$

$X G=X M D V^{*} P X M+X R D V^{*}(P X R D / 2+P X F D / 2)+X E D V * P X E D$

$X S N I=X S N I V^{*} P X S$

$X G S=X G+X S N I$

$P X G=X G /(X M D V+X R D V+X E D V)$

Income

KKD $=0.95^{*} K K D(-1)+G D I V D$

DIFGDP=GDPVD-GDPVDP

GDPVDP $=\operatorname{EXP}\left(9.216443-0.0016^{*} \mathrm{TIME}+0.6^{*} \mathrm{LOG}(\mathrm{KKD})\right)$

GDPVD $=2.582586 D+10+.6311223^{*}$ GDIVD+2.923915*GCVD+ADFGDP

RTRANS=NETFLOW-(IIDEBL+ADFIIL)/DEFUS

GDIVD $=1.559568 \mathrm{D}+10+.3955471^{*}$ RTRANS-4.583803D+08*TIME+ADFGDI

\section{Debt}

CHEXUS=LOG(1/EXCHUS)-LOG(1/EXCHUS(-1))

RATDEB $=$ RATDEB $(-1) /\left(1+(1-\text { RATDEB }(-1))^{*}\right.$ CHEXUS $)$

INTLT $=(\text { RATVAR }-3)^{*} 1.3^{*}$ IRSUS $/ 100+($ t-(RATVAR- -3$\left.)\right) * 09$

IIDEBL $=$ RATLT $^{*}(D O D(-1)+D O D) / 2 * I N T L T:$

IIDEBS $=(1-R A T L T)^{*}($ DOD $(-1)+$ DOD $) / 2 * 1.1 * I R S U S / 100$

$M S I=I I D E B L * 1.18+\| D E B S * 1.20+$ ADFMS

$X S I=I R S U S / 100^{*}(R E S / 2+R E S(-1) / 2) * 1.12+6.63 D+06^{*}$ TIME+ADFXS

TBD $=X G-M G$

CBNI=TBD+XSNI-MSNI+NTPRIV+NTOFF

$\mathrm{CBD}=\mathrm{CBNI}+\mathrm{XSI}-\mathrm{MSI}$

RES $=.7395928^{*} \mathrm{MGS}+.6064293^{*} \mathrm{CBD}+.6051025^{*} \mathrm{CBD}(-1)+\mathrm{ADFRES}$

NBORR=RES-RES(-1)-CBD-NDFI+ADFDEB

DOD $=D O D(-1)^{*}\left(1+(1-\text { RATDEB }(-1))^{*}\right.$ CHEXUS $)+$ NBORR

$D E=D O D /(X G+X S N I+X S I)$

$D G=D O D /\left(G D P V D * E X 80^{*}(G D P D E F / 100) / E X R A T E\right)$

$I E=I I D E B L(X G+X S N I+X S I)$

$N B G=N B O R R /\left(G D P V D^{*} E X 80^{*}(G D P D E F / 100) / E X R A T E\right)$ 


\section{Brazil}

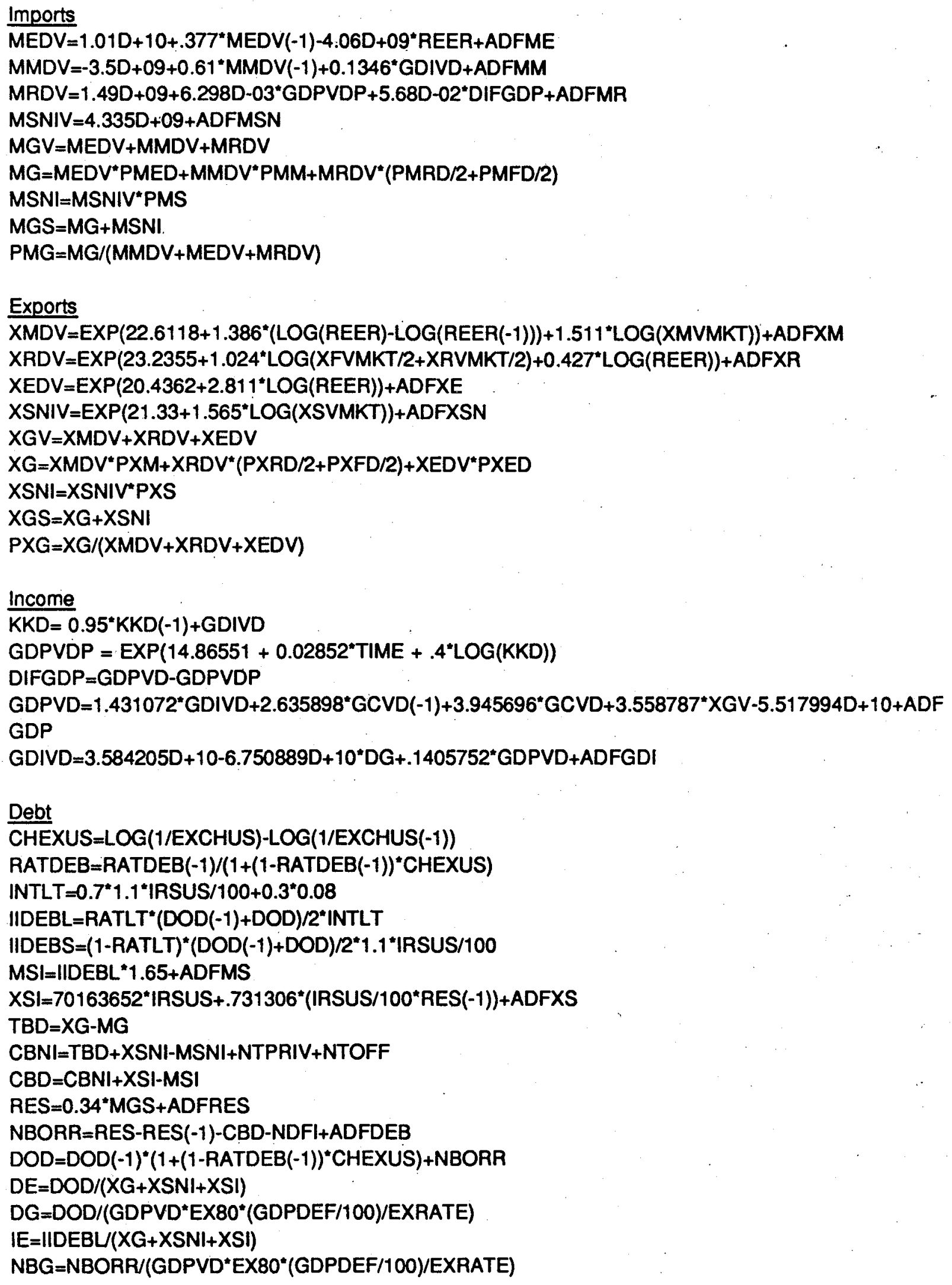


3. Chille

Imports

$M M D V=-3.326968 D+09+.1682045^{*}$ GDIVD+4.17279D+09*(GDPVD/GDPVDP) $+.3812264^{*} M M D V(-1)+A D$ FMM

$M E D V=-0.052^{*} G D P V D P+2.093 D+09^{*}(G D P V D / G D P V D P)+A D F M E$

$M R D V=7.0254 \mathrm{D}+08+7.38 \mathrm{D}-02^{*} \mathrm{DIFGDP}+\mathrm{ADFMR}$

$M S N I V=5.077 D-02 * G D P V D P+8.29 D-02^{*}$ DIFGDP+ADFMSN

$M G V=M E D V+M M D V+M R D V$

$M G=M E D V^{*} P M E D+M M D V * P M M+M R D V^{*}(P M R D / 2+P M F D / 2)$

$M S N I=M S N I V * P M S$

$M G S=M G+M S N I$

$P M G=M G /(M M D V+M E D V+M R D V)$

Exports

$X M D V=3.284 D+08^{*}(G D P V D / G D P V D P)+A D F X M$

$X R D V=E X P\left(22.03596+2.36^{*} L O G(X R V M K T / 2+X F V M K T / 2)\right)+A D F X R$

$X E D V=E X P\left(18.1807+1.14^{*} \mathrm{LOG}(X E V M K T)\right)+A D F X E$

$X S N I V=E X P\left(20.54723+2.438981^{*} L O G(X S V M K T)+2.004583^{*} L O G(G D P V D / G D P V D P)\right)+A D F X S N$

$X G V=X M D V+X R D V+X E D V$

$X G=X M D V^{*} P X M+X R D V^{*}(P X R D / 2+P X F D / 2)+X E D V^{*} P X E D$

$X S N I=X S N I V * P X S$

$X G S=X G+X S N I$

$P X G=X G /(X M D V+X R D V+X E D V)$

Income

KKD $=0.95^{*} K K D(-1)+$ GDIVD

DIFGDP=GDPVD-GDPVDP

GDPVDP $=$ EXP $\left(13.629+0.0251^{*} \mathrm{TIME}+0.4^{*} \mathrm{LOG}(\mathrm{KKD})\right)$

RTRANS=NETFLOW-(IIDEBL+ADFIIL)/DEFUS

GDIVD $=1.485898^{*}$ RTRANS $+.85459^{*} X G V+A D F G D I$

GDPVD $=1.787061 D+10+.7429465^{*}$ GDIVD $+1.470854^{*} X G V-3.3616460+09^{*} I N F L+A D F G D P$

Debt

CHEXUS $=$ LOG(1/EXCHUS)-LOG(1/EXCHUS(-1))

RATDEB $=$ RATDEB $(-1) /\left(1+(1-\text { RATDEB }(-1))^{*}\right.$ CHEXUS $)$

INTLT=RATVAR*1.3*IRSUS/100+(1-RATVAR) $: 07$

IIDEBL=RATLT*(DOD(-1)+DOD)/2*INTLT

IIDEBS $=(1-R A T L T)^{*}(\mathrm{DOD}(-1)+\mathrm{DOD}) / \mathbf{2}^{*} 1.1 *$ IRSUS/100

$M S \mid=I I D E B L * 1.44+$ ADFMS

$X S|=| R S U S / 100^{*}(\text { RES } / 2+R E S(-1) / 2)^{*} 1.36+$ ADFXS

$T B D=X G-M G$

CBNI=TBD+XSNI-MSNI+NTPRIV+NTOFF

$\mathrm{CBD}=\mathrm{CBNI}+\mathrm{XSI}-\mathrm{MSI}$

RES $=-6.6 \mathrm{D}+08+0.56^{*} \mathrm{MGS}+\mathrm{ADFRES}$

NBORR=RES-RES(-1)-CBD-NDFI+ADFDEB

$D O D=D O D(-1)^{*}\left(1+(1-\text { RATDEB }(-1))^{*}\right.$ CHEXUS $)+N B O R F$

$D E=D O D /(X G+X S N I+X S I)$

$D G=D O D /\left(G D P V{ }^{*} E X 80^{*}(G D P D E F / 100) / E X R A T E\right)$

$I E=I I D E B L / X G+X S N I+X S I)$

$N B G=N B O R R /\left(G D P V D * E X 80^{*}(G D P D E F / 100) / E X R A T E\right)$ 


\section{LAT-Other}

Imports

MMDV $=2.166 \mathrm{D}+10-2.426 \mathrm{D}+10^{*}$ (GDPVD/GDPVDP)+.743*GDIVD+ADFMM

$M E D V=1.923 D+10-.135^{*}$ GDPVDP+ADFME

$M R D V=4.876 D-02^{*}$ GDPVDP-6.749D+09*(GDPVD/GDPVDP)+.238*GDIVD+ADFMR

$M S N I V=1.775 D+09+4.365 D-02^{*}$ GDPVD+ADFMSN

$M G V=M E D V+M M D V+M R D V$

$M G=M E D V * P M E D+M M D V^{*} P M M+M R D V^{*}(P M R D / 2+P M F D / 2)$

MSNI=MSNIV*PMS

$M G S=M G+M S N I$

$P M G=M G /(M M D V+M E D V+M R D V)$

Exports

XMDV=EXP(21.9727+2.129*LOG(GDPVD/GDPVDP)+.309*LOG(XMVMKT))+ADFXM

$X R D V=\operatorname{EXP}\left(23.1588+.615^{*} \mathrm{LOG}(X F V M K T / 2+X R V M K T / 2)\right)+A D F X R$

$X E D V=E X P\left(22.377+.831^{\circ} \mathrm{LOG}(X E V M K T)\right)+A D F X E$

$X S N I V=E X P\left(22.48704+1.511419^{*} \mathrm{LOG}(X S V M K T)\right)+A D F X S N$

$X G V=X M D V+X R D V+X E D V$

$X G=X M D V^{*} P X M+X R D V^{*}(P X R D / 2+P X F D / 2)+X E D V^{*} P X E D$

$X S N I=X S N I V * P X S$

$X G S=X G+X S N I$

$P X G=X G /(X M D V+X R D V+X E D V)$

Income

KKD $=0.95^{*} K K D(-1)+$ GDIVD

DIFGDP=GDPVD-GDPVDP

GDPVDP=EXP(14.631455+0.0129*TIME+0.4*LOG(KKD))

RTRANS=NETFLOW-(IIDEBL+ADFIIL)/DEFUS

GDIVD $=1.27641^{*}$ RTRANS + $1.038389^{*} X G V(-1)-3.274274 D+09^{*}$ INFL+ADFGDI

GDPVD $=1.032499^{*} G D I V D+1.335243^{*} X G V+.8467255^{\star} G D P V D P-3.20513 D+10+A D F G D P$

Debt

CHEXUS $=$ LOG(1/EXCHUS)-LOG(1/EXCHUS(-1))

RATDEB=RATDEB $(-1) /\left(1+(1-\text { RATDEB }(-1))^{*}\right.$ CHEXUS)

INTLT $=0.6^{*} 1.0^{*}$ IRSUS $/ 100+0.4^{*} .04$

IIDEBL=RATLT* ${ }^{*}(D O D(-1)+D O D) / 2^{*}$ INTLT

IIDEBS $=(1-\mathrm{RATLT}) *(\mathrm{DOD}(-1)+\mathrm{DOD}) / 2^{*} 1.0 * \mathrm{RSUS} / 100$

$M S \mid=1.58^{*}\left\|D E B L+4.34^{*}\right\| D E B S+A D F M S$

$X S I=(I R S U S / 100+\operatorname{IRSUS}(-1) / 100) / 2 *$ RES $(-1)^{*} 5.35+$ ADFXS

$T B D=X G-M G$

CBNI=TBD+XSNI-MSNI+NTPRIV+NTOFF

$\mathrm{CBD}=\mathrm{CBNI}+\mathrm{XSI}-\mathrm{MSI}$

RES $=0.326^{*} M G S+A D F R E S$

NBORR $=$ RES-RES(-1)-CBD-NDFI+ADFDEB

DOD $=D O D(-1)^{*}\left(1+(1-\text { RATDEB }(-1))^{*}\right.$ CHEXUS $)+N B O R R$

$D E=D O D /(X G+X S N I+X S I)$

$D G=D O D /\left(G D P V D * E X 80^{*}(G D P D E F / 100) / E X R A T E\right)$

$I E=I I D E B L(X G+X S N I+X S I)$

$N B G=N B O R R /(G D P V D *(G D P D E F / 100) / E X R A T E)$ 


\section{Mexico}

Imports

MMDV $=.498^{*}$ GDIVD+2.13D-02*GDPVDP-1.397D+10*(GDPVD/GDPVDP)+ADFMM

$M E D V=1.061 D+09-4.081 D+07^{\circ} \mathrm{TIME}+\mathrm{ADFME}$

$M R D V=.099^{*}$ GDIVD+2.29D-02*GDPVDP-5.625D+09*(GDPVD/GDPVDP)+ADFMR

$M S N I V=5.275 D+09+0.1^{*} \mathrm{DIFGDP}+\mathrm{ADFMSN}$

$M G V=M E D V+M M D V+M R D V$

$M G=M E D V^{*} P M E D+M M D V^{*} P M M+M R D V^{*}(P M R D / 2+P M F D / 2)$

$M S N I=M S N I V^{*} P M S$

$M G S=M G+M S N I$

$P M G=M G /(M M D V+M E D V+M R D V)$

\section{Exports}

XMDV=EXP(21.6735+2.2*LOG(XMVMKT)-2.35*LOG(GDPVD/GDPVDP))+ADFXM $X R D V=\operatorname{EXP}(21.94+1.39 * \mathrm{LOG}(X R V M K T / 2+X F V M K T / 2))+A D F X R$

$X E D V=X E D V+A D F X E$

$X S N I V=E X P\left(22.552+1.055^{*} L O G(X S V M K T)\right)+A D F X S N$

$X G V=X M D V+X R D V+X E D V$

$X G=X M D V^{*} P X M+X R D V^{*}(P X R D / 2+P X F D / 2)+X E D V^{*} P X E D$

$X S N I=X S N I V * P X S$

$X G S=X G+X S N I$

$P X G=X G /(X M D V+X R D V+X E D V)$

Income

KKD $=0.95^{*} K K D(-1)+$ GDIVD

DIFGDP $=$ GDPVD-GDPVDP

GDPVDP=EXP(14.8185+0.0226*TIME+0.4*LOG(KKD))

GDIVD $=-3.207825 D+10+.4317696^{*}$ GDPVD $+1.449748^{*}$ RTRANS-2.534538D+10*INFL+ADFGDI

GDPVD $=9.922875 D+10+.9411593^{*} \mathrm{GDIVD}+3.047393^{*} \times G V+A D F G D P$

Debt

CHEXUS=LOG(1/EXCHUS)-LOG(1/EXCHUS(-1))

RATDEB=RATDEB $(-1) /\left(1+(1-\operatorname{RATDEB}(-1))^{*}\right.$ CHEXUS)

INTLT $=0.8^{*} 1.3^{*}$ IRSUS $/ 100+0.2^{*} .09$

IIDEBL $=R A T L T^{*}(D O D(-1)+D O D) / 2^{*} I N T L T$

IIDEBS $=(1-\text { RATLT })^{*}(\mathrm{DOD}(-1)+\mathrm{DOD}) / 2^{*} 1.1 *$ IRSUS $/ 100$

$M S \mid=\|I D E B L * 1.2+\| D E B S * 1.1+A D F M S$

$X S \mid=-1.041 \mathrm{D}+09+1.368 \mathrm{D}+08^{\circ} \mathrm{TIME}^{\circ} .89^{*}\left(\mathrm{RES}^{*} \mathrm{IRSUS} / 100\right)+$ ADFXS

RTRANS=NETFLOW-(IIDEBL+ADFIIL)/DEFUS

$T B D=X G-M G$

CBNI=TBD+XSNI-MSNI+NTPRIV+NTOFF

$\mathrm{CBD}=\mathrm{CBNI}+\mathrm{XSI}-\mathrm{MSI}$

RES $=$ RES $(-1)+.575^{*}($ CBD-CBD $(-1))+.46^{*}($ MGS-MGS(-1))+ADFRES

NBORR=RES-RES(-1)-CBD-NDFI+ADFDEB

DOD $=D O D(-1)^{*}\left(1+(1-\text { RATDEB }(-1))^{*}\right.$ CHEXUS $)+$ NBORR

$D E=D O D /(X G+X S N I+X S I)$.

$D G=D O D /\left(G D P V D * E X 80^{*}(G D P D E F / 100) / E X R A T E\right)$

$I E=I I D E B L(X G+X S N I+X S I)$

$N B G=N B O R R /\left(G D P V D * E X 80^{*}(G D P D E F / 100) / E X R A T E\right)$ 
Appendix C: Estimation

\section{Glossary of Varlables Referred to in Tables}

CAPUT

CBD

CONST

DG

DIFGDP

GCVD

GDIVD

GDPVD

GDPVDP

IIDEBL

IIDEBS

INFL

IRSUS

MEDV

MGS

MMDV

REER

RES

RTRANS

TIME

XEVMKT

XGV

XMVMKT

XRAMKT

XSVMKT
Capacity utilization (GDPVD/GDPVDP)

Current account balance in current $\$$

Intercept

Debt to GDP ratio

Difference between actual and potential production

Government consumption in constant \$

Gross domestic investment in constant \$

Gross domestic product in constant \$

Potential production in constant $\$$

Scheduled interest payments on long-term debt

Scheduled (estimated) interest payments on short-term debt

Domestic inflation measured by the GDP deflator

Short term US interest rate

Imports of Energy in constant \$

Imports of goods and services in current \$

Imports of Manufactures in constant \$

Real exchange rate (dREER $>0$ indicates depreciation)

Reserves in current \$

Real net long-term lending (disbursement-amortization-interest payments in constant \$)

Time trend

Market growth for Latin America for energy exports

Exports of goods and services in constant $\$$

Market growth for Latin America for manufactures exports

Market growth for Latin America for raw materials/food exports

Market growth for Latin America for services exports 
Table 1

Imports of Manufactured Goods

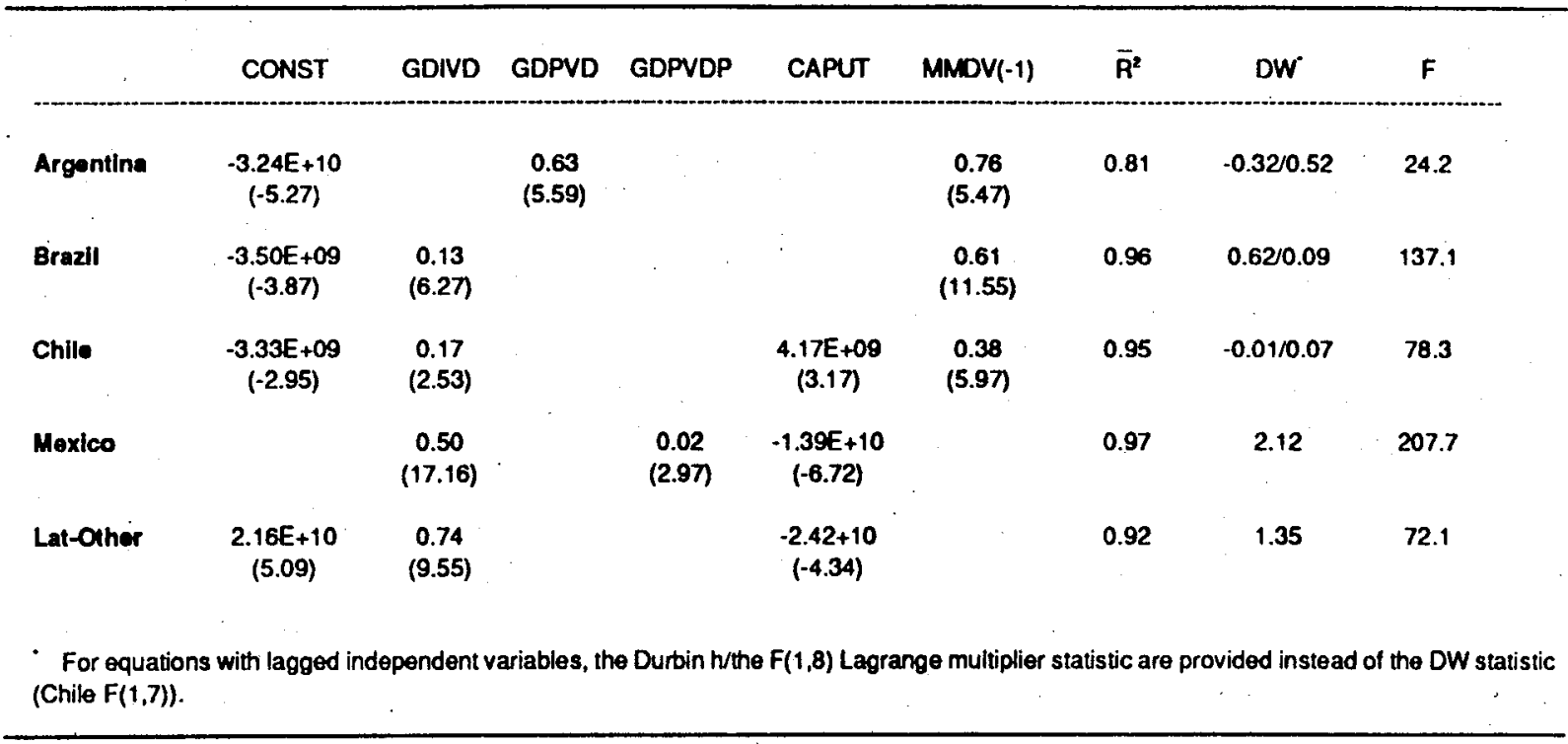

Table 2

Imports of Raw Materlals

\begin{tabular}{|c|c|c|c|c|c|c|c|c|c|}
\hline & CONST & GDIVD & GDPVD & GDPVDP & CAPUT & DIFGDP & $\overline{\mathbf{R}^{2}}$ & DW & $F$ \\
\hline Argentina & $\begin{array}{c}-3.70 E+9 \\
(-2.06)\end{array}$ & & $\begin{array}{c}0.09 \\
(2.59)\end{array}$ & & & & 0.32 & 0.99 & 6.75 \\
\hline Brazil & $\begin{array}{c}1.49 E+9 \\
(2.36)\end{array}$ & & $\begin{array}{l}0.006 \\
(2.31)\end{array}$ & & & $\begin{array}{l}0.057 \\
(5.89)\end{array}$ & 0.76 & 2.69 & 20.36 \\
\hline Chile & $\begin{array}{c}2.75 E+7 \\
(25.47)\end{array}$ & & & & & $\begin{array}{l}0.074 \\
(4.72)\end{array}$ & 0.63 & 2.96 & 22.3 \\
\hline Mexico & . & $\begin{array}{c}0.10 \\
(6.52)\end{array}$ & & $\begin{array}{l}0.023 \\
(6.08)\end{array}$ & $\begin{array}{c}-5.62 E+9 \\
(-5.15)\end{array}$ & & 0.85 & 1.84 & 35.4 \\
\hline Lat-Other & & $\begin{array}{c}0.24 \\
(10.14)\end{array}$ & $\therefore$ & $\begin{array}{l}0.049 \\
(10.9)\end{array}$ & $\begin{array}{c}-6.75 E+9 \\
(-9.18)\end{array}$ & & 0.95 & 2.11 & 111.9 \\
\hline
\end{tabular}

Table 3

Imports of Energy

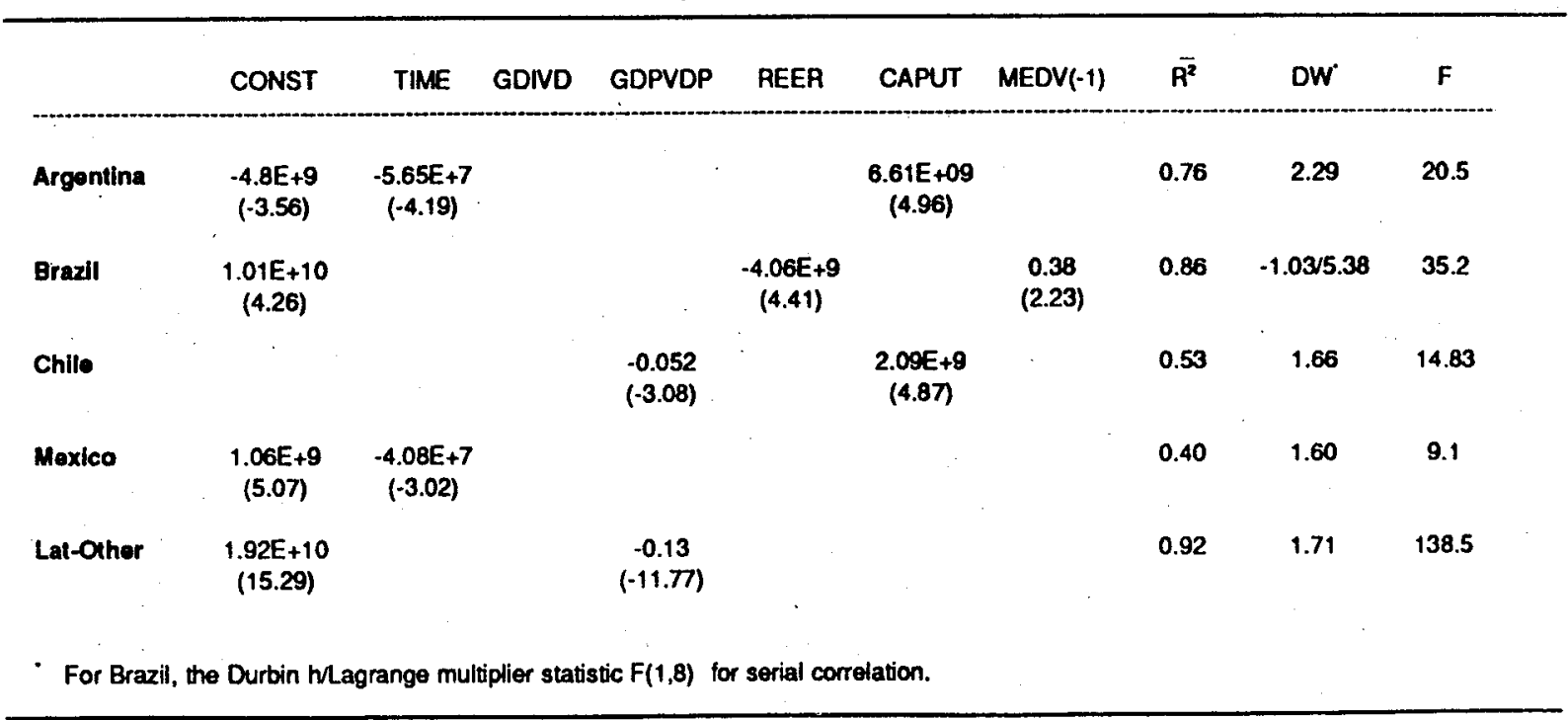


Table 4

Imports of Non-Factor Services

\begin{tabular}{|c|c|c|c|c|c|c|c|c|}
\hline & CONST & GDPVD & GDPVDP & CAPUT & DIFGDP & $\overline{\mathrm{A}}^{2}$ & DW & $F$ \\
\hline Argontina & $\begin{array}{c}-3.29 E+10 \\
(-4.44)\end{array}$ & & $\begin{array}{c}0.47 \\
(4.05)\end{array}$ & $\begin{array}{c}1.08 E+10 \\
(3.45)\end{array}$ & & 0.63 & 1.39 & 11.52 \\
\hline Brazll & $\begin{array}{c}4.33 E+9 \\
(24.8)\end{array}$ & & & & & - & - & - \\
\hline Chillo & & & $\begin{array}{c}0.051 \\
(35.56)\end{array}$ & & $\begin{array}{l}0.083 \\
(4.04)\end{array}$ & 0.71 & 1.63 & 30.7 \\
\hline Moxico & $\begin{array}{c}5.27 E+9 \\
(19.84)\end{array}$ & & & & $\begin{array}{c}0.10 \\
(4.16)\end{array}$ & 0.57 & 1.53 & 17.3 \\
\hline Lat-Orhor & $\begin{array}{c}1.77 E+9 \\
(2.86)\end{array}$ & $\begin{array}{l}0.044 \\
(7.73)\end{array}$ & & & & 0.83 & 1.61 & 59.8 \\
\hline
\end{tabular}

Table 5

Exports of Manufactures

(All variables in logarithmic form)

\begin{tabular}{|c|c|c|c|c|c|c|c|c|}
\hline & CONST & XMVMKT & REER & SREER & CAPUT & $\overline{\mathrm{A}}^{2}$ & DW & $\mathbf{F}$ \\
\hline Argontina & $\begin{array}{c}21.28 \\
(416.8)\end{array}$ & $\begin{array}{c}0.28 \\
(1.45)\end{array}$ & $\begin{array}{c}2.70 \\
(3.35)\end{array}$ & & & 0.43 & 1.66 & 5.7 \\
\hline Brazil & $\begin{array}{c}22.61 \\
(516.8)\end{array}$ & $\begin{array}{c}1.51 \\
(7.67)\end{array}$ & & $\begin{array}{l}1.39 \\
(3.68)\end{array}$ & . & 0.85 & 1.65 & 33.3 \\
\hline Chile: & & & & & $\begin{array}{c}3.28 E+8 \\
(26.5)\end{array}$ & 0.19 & 2.34 & - \\
\hline Moxico & $\begin{array}{c}21.67 \\
(613.4)\end{array}$ & $\begin{array}{c}2.2 \\
(14.73)\end{array}$ & & & $\begin{array}{c}-2.35 \\
(-3.80)\end{array}$ & 0.95 & 2.68 & 113.4 \\
\hline Lat-Orher & $\begin{array}{c}21.97 \\
(831.0)\end{array}$ & $\begin{array}{c}0.31 \\
(2.76)\end{array}$ & & & $\begin{array}{c}2.13 \\
(2.61)\end{array}$ & 0.54 & 0.84 & 7.96 \\
\hline
\end{tabular}

Table 6

Exports of Raw Materlals

(All variables in logarithmic form)

\begin{tabular}{|c|c|c|c|c|c|c|}
\hline & CONST & XRAMKT & PEER & $\overline{\mathrm{A}}^{2}$ & DW & $\mathbf{F}$ \\
\hline Argentina & $\begin{array}{c}22.52 \\
(540.1)\end{array}$ & $\begin{array}{r}1.59 \\
(4.26)\end{array}$ & & 0.59 & 1.05 & 18.1 \\
\hline Brazil & $\begin{array}{c}23.23 \\
(742.3)\end{array}$ & $\begin{array}{l}1.02 \\
(2.97)\end{array}$ & $\begin{array}{l}0.43 \\
(2.18)\end{array}$ & 0.80 & 1.98 & 25.5 \\
\hline Chile & $\begin{array}{c}22.03 \\
(723.5)\end{array}$ & $\begin{array}{c}2.36 \\
(8.61)\end{array}$ & & 0.85 & 1.37 & 74.1 \\
\hline Moxico & $\begin{array}{c}21.94 \\
(692.6)\end{array}$ & $\begin{array}{c}1.39 \\
(4.89)\end{array}$ & & 0.65 & 2.82 & 23.9 \\
\hline Let-OThor & $\begin{array}{c}23.16 \\
(1185.7)\end{array}$ & $\begin{array}{l}0.61 \\
(3.5)\end{array}$ & & 0.48 & 1.86 & 12.2 \\
\hline
\end{tabular}


Table 7

Exports of Energy

(All variables in logarithmic form)

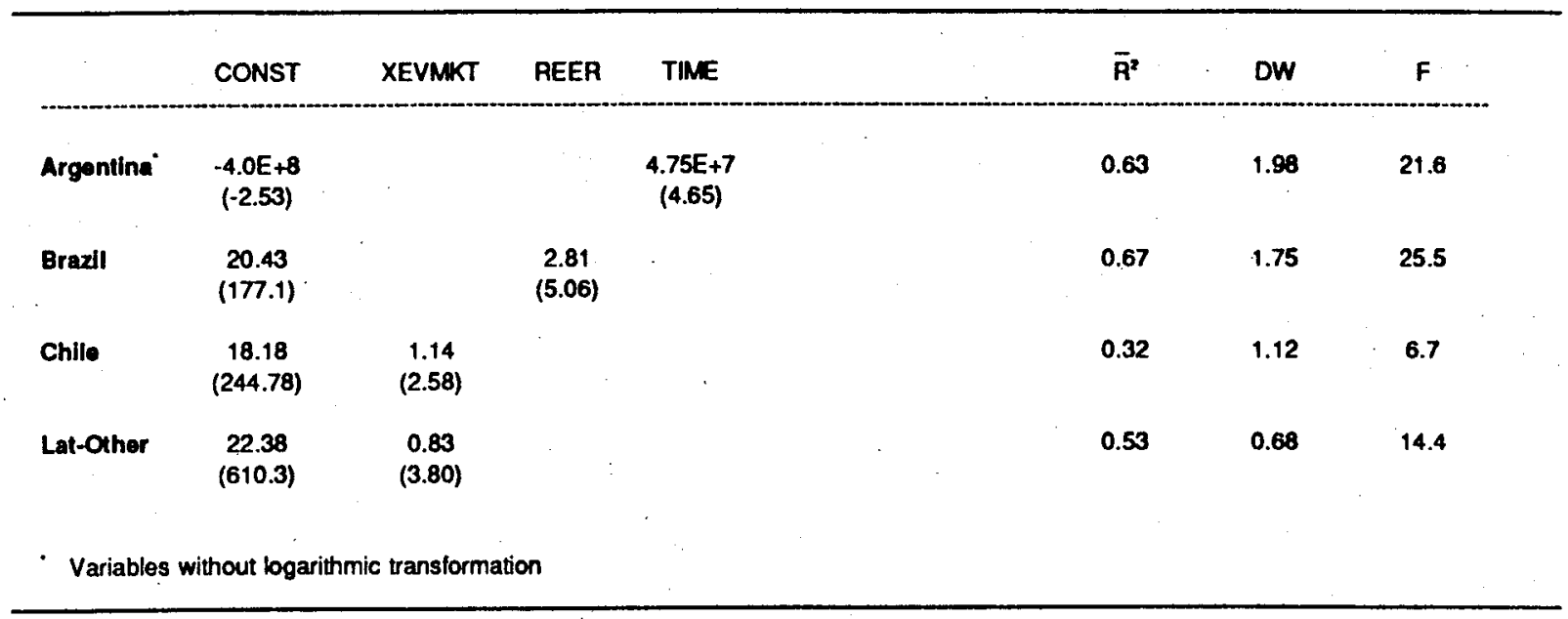

Table 8

Exports of Non-Factor Services

(All variables in logarithmic form)

\begin{tabular}{|c|c|c|c|c|c|c|}
\hline & CONST & XSVM:KT & CAPUT & $\overline{\mathrm{R}}^{2}$ & DW & $F$ \\
\hline Argentina & $\begin{array}{c}21.32 \\
(461.6)\end{array}$ & $\begin{array}{c}2.31 \\
(5.07)\end{array}$ & & 0.69 & 1.56 & 25.7 \\
\hline Brazil & $\begin{array}{c}21.33 \\
(846.9)\end{array}$ & $\begin{array}{c}1.56 \\
(6.31)\end{array}$ & & 0.78 & 2.11 & 39.8 \\
\hline Chile & $\begin{array}{c}20.55 \\
(543.3)\end{array}$ & $\begin{array}{c}2.44 \\
(6.58)\end{array}$ & $\begin{array}{c}2.00 \\
(3.65)\end{array}$ & 0.84 & 1.97 & 29.2 \\
\hline Mexico & $\begin{array}{c}22.55 \\
(431.1)\end{array}$ & $\begin{array}{c}1.05 \\
(2.05)\end{array}$ & & 0.22 & 1.85 & 4.2 \\
\hline Lat-Other & $\begin{array}{c}22.49 \\
(917.9)\end{array}$ & $\begin{array}{c}1.51 \\
(6.26)\end{array}$ & & 0.78 & 1.05 & 39.2 \\
\hline
\end{tabular}

Table 9

Gross Domestic Investment

\begin{tabular}{|c|c|c|c|c|c|c|c|c|c|}
\hline & CONST & GDPVD & RTRANS & INFL & $D G$ & $X G V$ & $\overline{\mathrm{R}}^{2}$ & DW & $\mathbf{F}$ \\
\hline Argentina & $\begin{array}{c}1.56 \mathrm{E}+10 \\
(8.73)\end{array}$ & & $\begin{array}{c}0.39 \\
(1.98)\end{array}$ & & & $\begin{array}{c}-4.5 E+8^{\circ} \\
(-4.0)\end{array}$ & 0.68 & 1.80 & 14.0 \\
\hline Brazil & $\begin{array}{c}3.58 E+10 \\
(6.11)\end{array}$ & $\begin{array}{c}0.14 \\
(4.06)\end{array}$ & & & $\begin{array}{c}-6.75 E+10 \\
(-5.7 \eta\end{array}$ & & 0.77 & 1.88 & 16.7 \\
\hline Chile & & & $\begin{array}{r}1.49 \\
(6.27)\end{array}$ & & & $\begin{array}{r}0.85 \\
(19.4)\end{array}$ & 0.81 & 2.22 & 46.5 \\
\hline Mexico & $\begin{array}{c}-3.21 E+10 \\
(-4.79)\end{array}$ & $\begin{array}{c}0.43 \\
(11.6)\end{array}$ & $\begin{array}{c}1.45 \\
(6.97)\end{array}$ & $\begin{array}{c}-2.53 E+10 \\
(-5.95)\end{array}$ & . & & 0.94 & 2.66 & 58.0 \\
\hline Lat-Other & & & $\begin{array}{c}1.28 \\
(4.16)\end{array}$ & $\begin{array}{c}-3.27 E+9 \\
(-2.24)\end{array}$ & : & $\begin{array}{c}1.04^{\circ} \\
(47.6)\end{array}$ & 0.82 & 1.02 & 26.2 \\
\hline
\end{tabular}


Table 10

Gross Domestlc Product

\begin{tabular}{|c|c|c|c|c|c|c|c|c|c|c|}
\hline & CONST & GDIVD & $x G V$ & GDPVDP & GCVD & $\operatorname{GCVD}(-1)$ & INFL & $\overline{\mathrm{R}}^{2}$ & DW & $F$ \\
\hline Argentine & $\begin{array}{c}2.58 E+10 \\
(5.27)\end{array}$ & $\begin{array}{c}0.63 \\
(4.79)\end{array}$ & & & $\begin{array}{c}2.82 \\
(4.89)\end{array}$ & & & 0.72 & 2.12 & 17.1 \\
\hline Brazil & $\begin{array}{c}-5.52 E+10 \\
(-3.25)\end{array}$ & $\begin{array}{c}1.43 \\
(4.59)\end{array}$ & $\begin{array}{c}3.56 \\
(9.56)\end{array}$ & & $\begin{array}{c}3.94 \\
(5.93)\end{array}$ & $\begin{array}{c}2.64 \\
(4.22)\end{array}$ & & 0.97 & 1.37 & 133.9 \\
\hline Chillo & $\begin{array}{c}1.79 E+10 \\
(14.2)\end{array}$ & $\begin{array}{c}0.74 \\
(5.62)\end{array}$ & $\begin{array}{c}1.47 \\
(6.36)\end{array}$ & & & & $-3.38 E+8$ & 0.96 & 1.54 & 93.0 \\
\hline Mextco & $\begin{array}{c}9.92 E+10 \\
(18.9)\end{array}$ & $\begin{array}{c}0.94 \\
(7.39)\end{array}$ & $\begin{array}{c}3.05 \\
(22.04)\end{array}$ & & & & & 0.87 & 1.73 & 284.4 \\
\hline Lat-Orher & $\begin{array}{c}-3.20 E+10 \\
(-7.57)\end{array}$ & $\begin{array}{c}1.03 \\
(8.44)\end{array}$ & $\begin{array}{c}1.33 \\
(5.98)\end{array}$ & $\begin{array}{c}0.85 \\
(25.2)\end{array}$ & & & . & 0.99 & 2.47 & 418.6 \\
\hline
\end{tabular}

Table 11

Factor Services Imports

\begin{tabular}{|c|c|c|c|c|c|}
\hline & IIDEBL & IIDEBS & $\overline{\mathrm{A}^{2}}$ & DW & $F$ \\
\hline Argontlna & $\begin{array}{c}1.18 \\
(17.42)\end{array}$ & $\begin{array}{l}1.20 \\
(6.74)\end{array}$ & 0.97 & 1.01 & 399.8 \\
\hline Brezil & $\begin{array}{c}1.65 \\
(27.22)\end{array}$ & & 0.89 & 1.78 & - \\
\hline chile & $\begin{array}{c}1.44 \\
(36.16)\end{array}$ & & 0.96 & 1.65 & \\
\hline Moxleo & $\begin{array}{c}1.20 \\
(14.43)\end{array}$ & $\begin{array}{c}1.10 \\
(3.13)\end{array}$ & 0.94 & 2.45 & 163.7 \\
\hline Lat-Othor & $\begin{array}{c}1.58 \\
(4.61)\end{array}$ & $\begin{array}{c}4.34 \\
(4.50)\end{array}$ & 0.94 & 1.81 & 183.3 \\
\hline
\end{tabular}


Table 12

Exports of Factor Sorvices

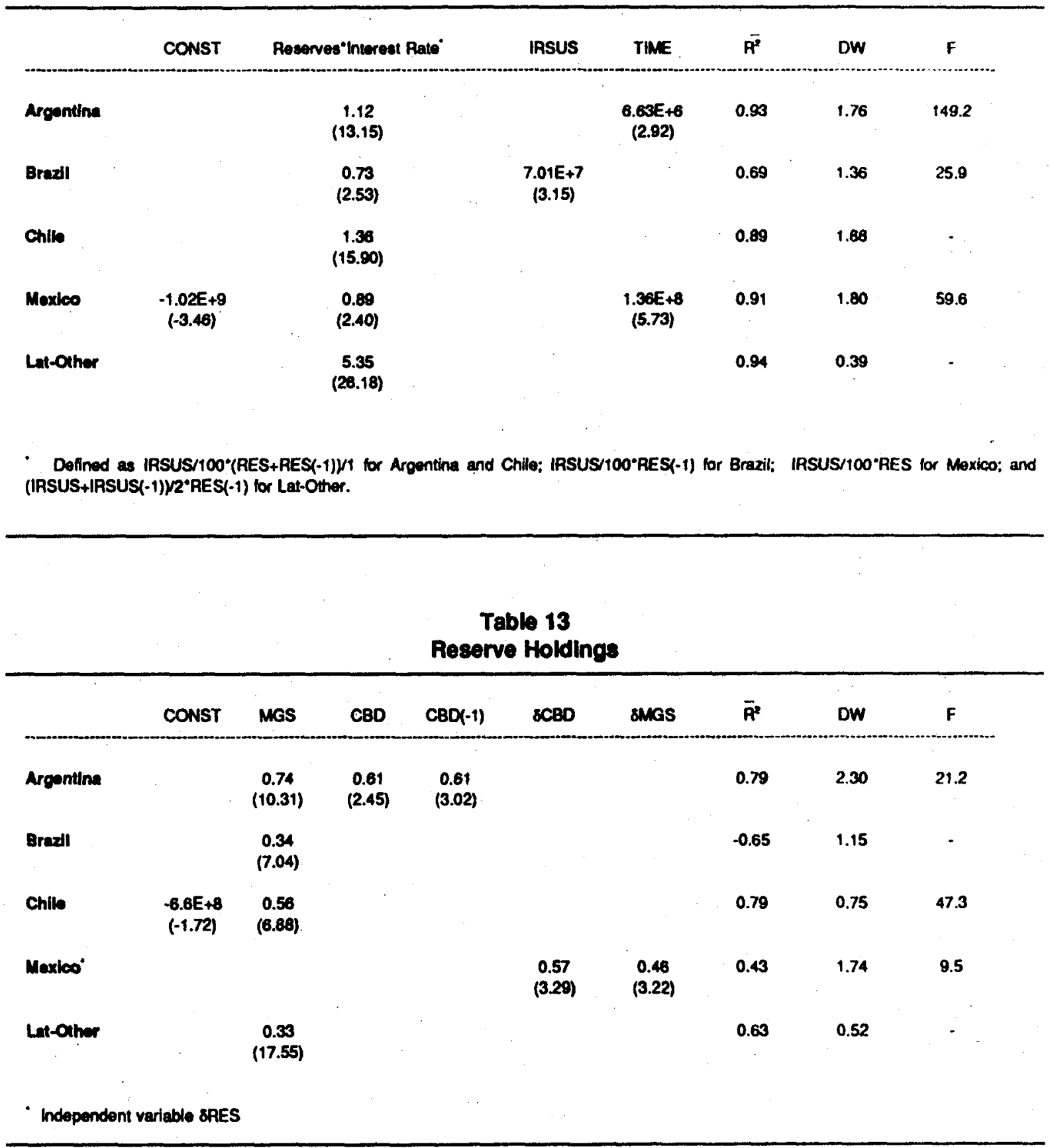


Table 14

OCED GDP Increases by One Percentage Point

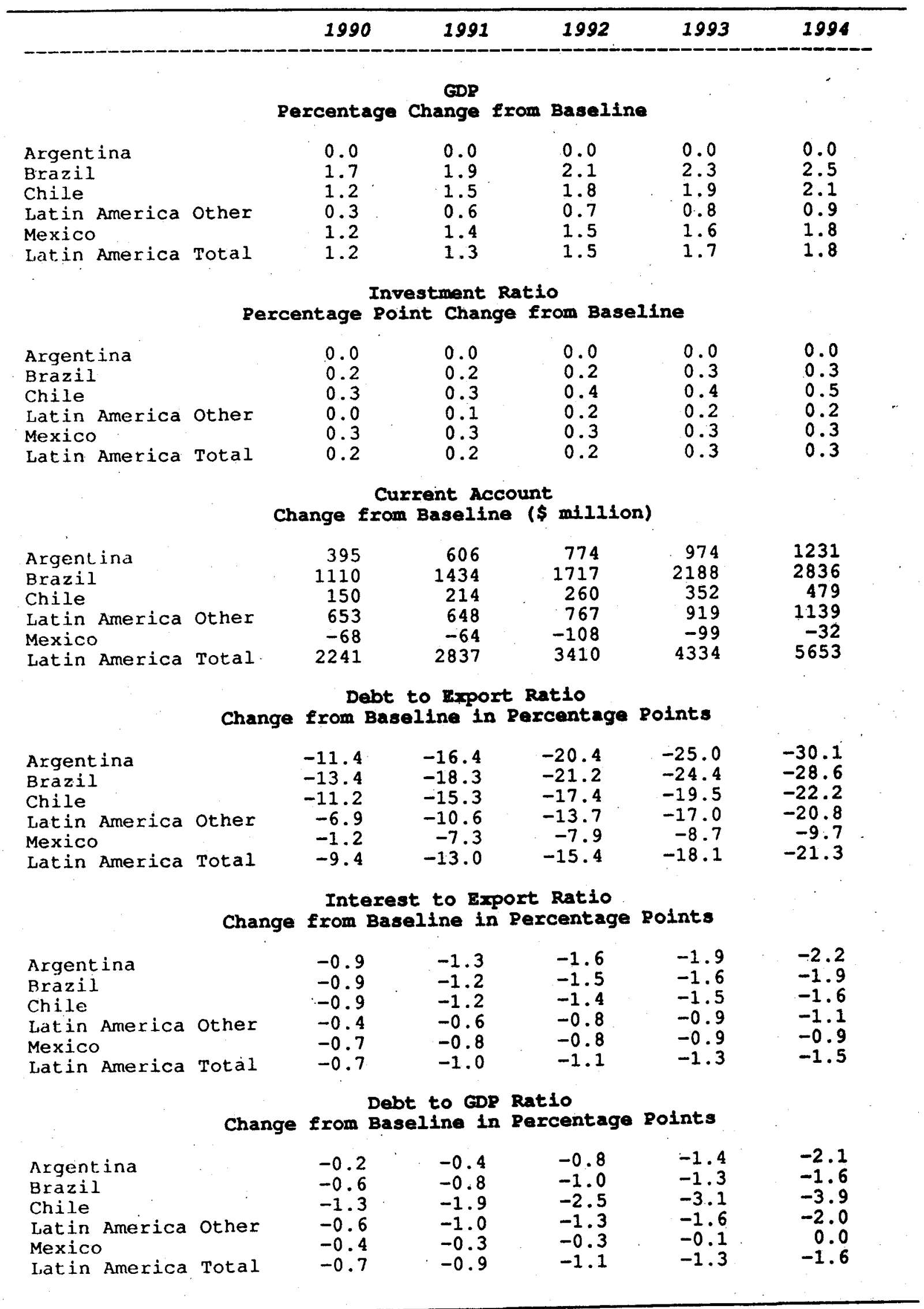


Table 15

Increase of US Short Term Interest Rate by One Percentage Point

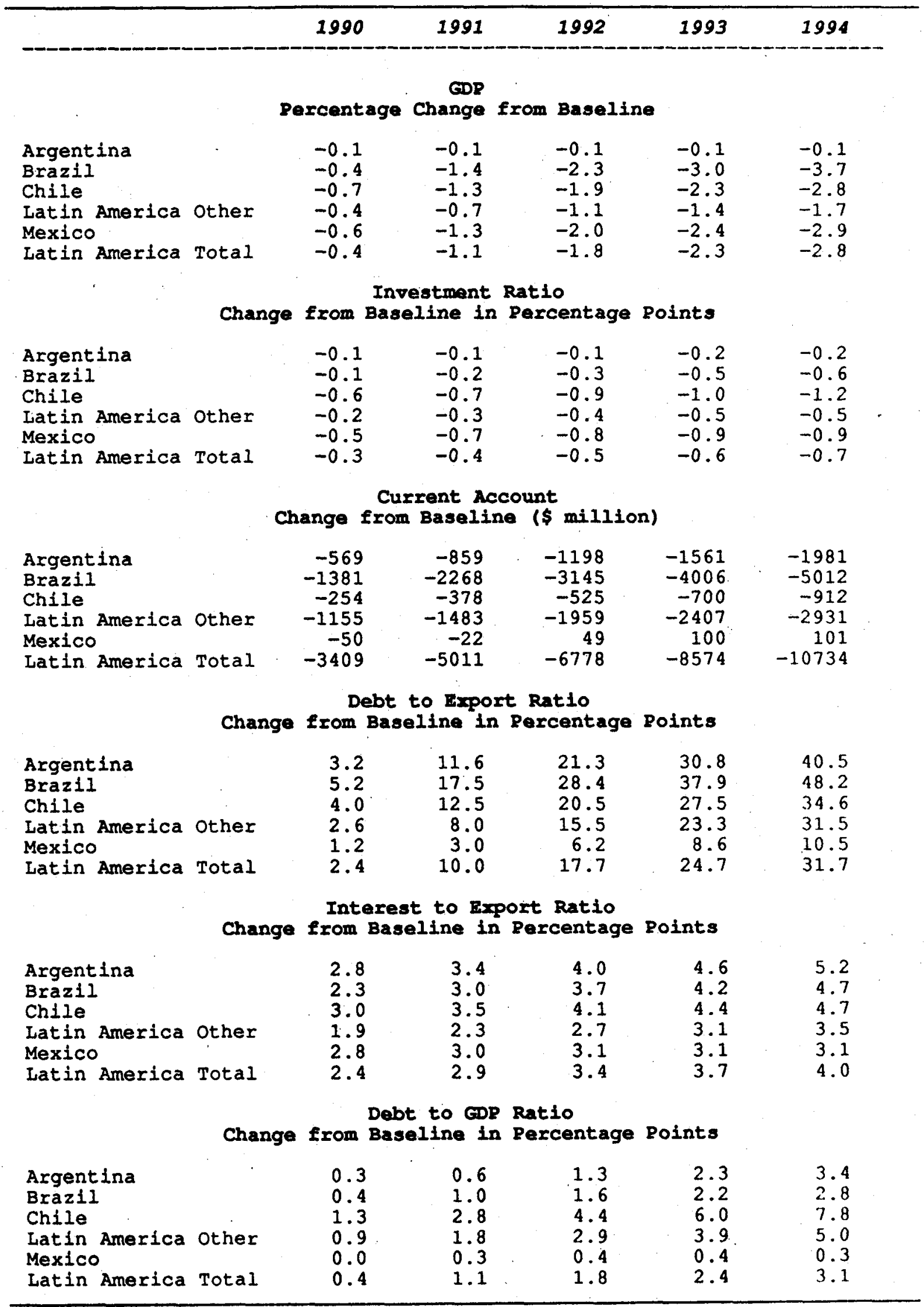


Table 16

Increase in Net Flows Equivalent to Debt Reduction of 15 per cent

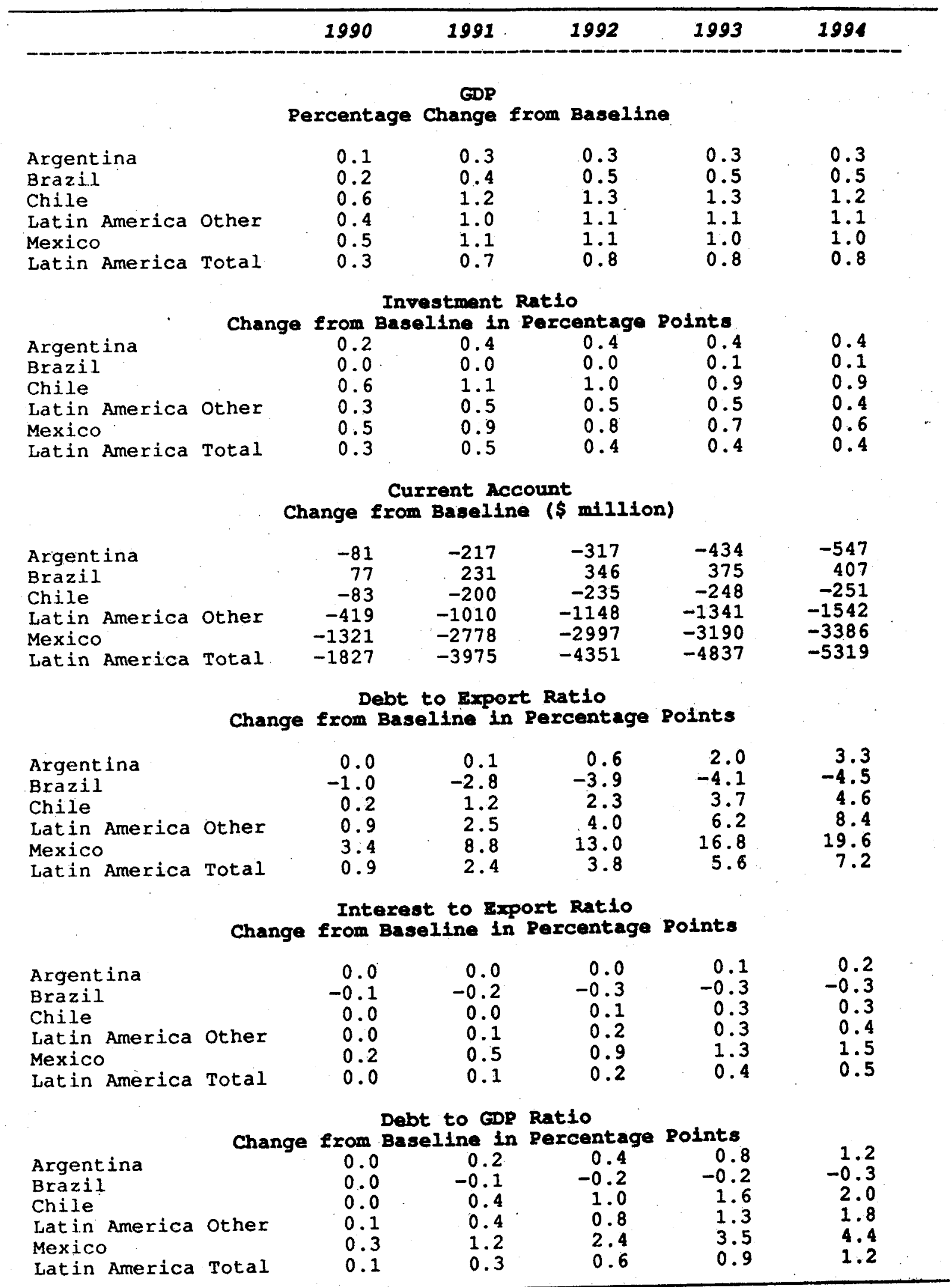




\section{Appendlx E: HIC Models}

The 17 HICs grouped by Interlink region

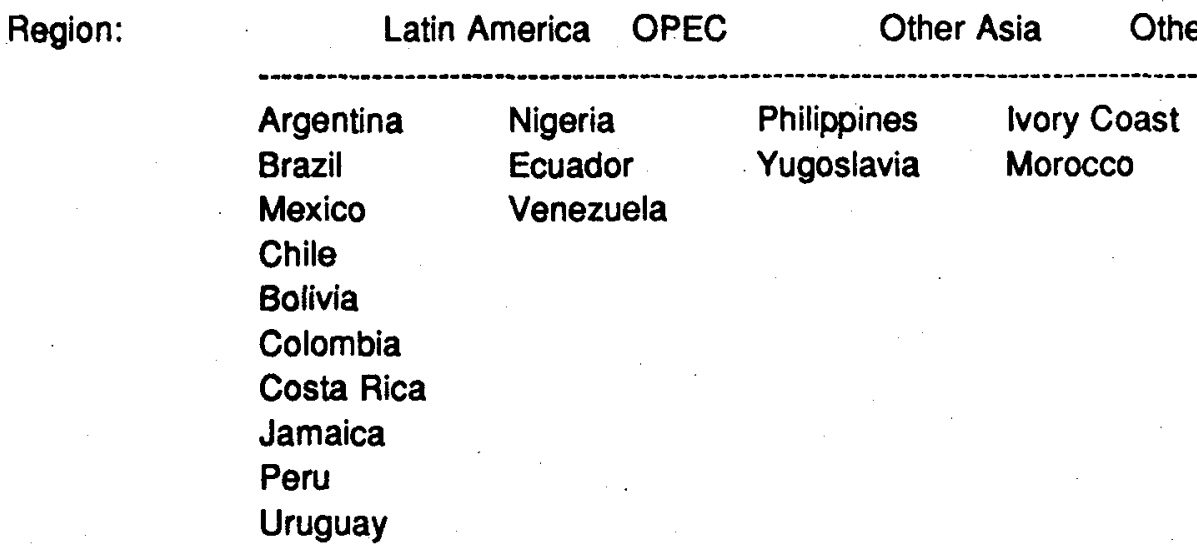

The equations: $\quad X G S_{1}=a_{1} * X G S_{h}$

$$
\begin{aligned}
& a_{1} \equiv X G S_{1} \text { (baseline) / } X G S_{R} \text { (baseline) } \\
& M G S_{1}=b_{1} * M^{*} S_{R} \\
& b_{1} \equiv M G S_{1} \text { (baseline) / } M S_{R} \text { (baseline) } \\
& X S I_{1}=\text { IRSUS * XSI, (baseline) / IRSUS (baseline) } \\
& \text { IIDEBL }=\text { LTD * } \text { (SFX*RFX + (1-SFX)*DD*IRSUS/100\} } \\
& \text { IIDEBS }=\text { STD * (IRSUS }+ \text { MK) } / 100 \\
& M S I=E A *\left\{E E^{*} I I D E B L+(2-E E) * \| I D E B S\right\}+A D \\
& \mathrm{LTD}=\mathrm{LTD}_{.1}-\mathrm{CBD} * \mathrm{LTD}_{.1} /\left(\mathrm{STD}_{-1}+\mathrm{LTD}_{.1}\right) \\
& \text { STD }=\text { STD }_{-1} \cdot \mathrm{CBD}^{*} \mathrm{STD}_{-1} /\left(\mathrm{STD}_{-1}+\mathrm{LTD}_{-1}\right)
\end{aligned}
$$

(variable names are the same as in DEMOD; subscripts $i$ and $\mathbf{R}$ refer to corresponding countries and regions as in the table above; debt stocks and interest payment flows are measured in millions of US dolliars).

\begin{tabular}{lllllll} 
Coefficient values & DD & MK & EA & EE & AD & RFX \\
\cline { 2 - 6 } & 1.0 & 1.0 & 1.0 & 1.6 & 0 & 0.06 \\
Argentina & 1.1 & 1.0 & 1.0 & 1.6 & 0 & 0.06 \\
Brazil & 1.1 & 1.0 & 1.0 & 1.4 & 0 & 0.06 \\
Chile & 1.2 & 1.0 & 0.9 & 1.6 & 0 & 0.055 \\
Mexico & 1.2 & 1.0 & 1.2 & 1.6 & 0 & 0.04 \\
Bolivia & 1.1 & 1.0 & 1.0 & 2.0 & 0 & 0.06 \\
Colombia & 1.0 & 1.0 & 1.0 & 1.2 & 0 & 0.06 \\
Costa Rica & 1.2 & 1.0 & 2.0 & 1.0 & 0 & 0.06 \\
Jamaica & 1.0 & 1.0 & 1.0 & 1.5 & 0 & 0.06 \\
Peru & 1.4 & 2.0 & 1.0 & 1.6 & 0 & 0.06 \\
Uruguay & 1.0 & 1.0 & 1.0 & 1.0 & 500 & 0.06 \\
Nigeria & 1.5 & 1.0 & 1.0 & 1.0 & 100 & 0.035 \\
Ecuador & 1.0 & 2.0 & 1.0 & 1.4 & 200 & 0.06 \\
Venzuela & 0.95 & 0.0 & 1.0 & 1.6 & 200 & 0.06 \\
Philippines & 1.3 & 1.0 & 1.0 & 1.4 & -300 & 0.06 \\
Yugoslavia & 1.3 & 2.0 & 1.0 & 1.0 & 0 & 0.06 \\
Ivory Coast & 1.1 & 3.0 & 0.85 & 1.5 & 0 & 0.04 \\
Morocco & & & & & &
\end{tabular}


In April 1983, the Economics and Statistics Department initiated a new series of " economic studies entit led ESD Working Papers.

The following titles have been circulated:

1. Use of Demand Elasticities in Estimating Energy Demand (out of print)

Utilisation des élasticités de la demande dans l'estimation de la demande de

l'ónergie

Nxel. Mittelstädt

2. Capital, Energy and Labour Substitution: The Supply Block in OECD Medium-Term Models

Substitution du capital, de l'énergie et du travall : le bloc de l'offre dans les modeles à moyen terme de l'OCDF (épuisé)

l'at rick Artus

3. Wacge Formation in France: Sectoral Aspects (out of print)

formation des salaires en France : aspects sectoriels (épuisé)

Pat.rick Artus

1. Service Lives of Fixed Assets (out of print)

Duréo de vie utile des actifs fixes (épuisé)

Derok Blades

b. Resource Prices and Macroeconomic Policies: Lessons from Two O11 Price Shocks prix des ressources naturelles et politique macro-économique : les enselgnements de deux chocs pétroliers (épuisé)

John Llewellyn

6. Output Responsiveness and Inflation: An Aggregate Study Souplesse de la production et inflation : étude globale David T. Coe and Gerald Holtham

1. T'he Determinants of Exchange Rate Movements (out of print) lies déterminants des mouvements des taux de change (épulsé) Graham llacche

4. Simulated Macroeconomic Effects of a Large Fall in 011 Prices (out of print) sinulation des effets macro-économiques d'une forte balsse des prix pétroliers l. lemming Larsen and John Llewellyn

9. Modium-Term Financial Strategy: The Co-ordination of Fiscal Monetary Policy (out of print)

Stratégie financière à moyen terme : la coordination des politiques monétalre et budgrtal alre (épuísé)

Jean-claude Chouraqul and Robert Price

10. Price Dynamics and Industrial Structure: A Theoretical and Econometric Analysis (out of print)

Dynamique des prix et structure industrielle : une analyse théorique économétrique (épuisé)

Davtd Encaoua (with collaboration from Paul Gerosk1 and Riel Miller) 
11. Evidence on Income Distribution by Governments (out of print) L'Action exercée par l'Etat sur la redistribution du revenu Peter Saunders

12. Labour Force Participation: An Analysis with Projections Taux d'activité : analyse et projections James H. Chan-Lee

13. The Demand for Money and Velocity in Major OECD Countries (out of print) La demande de monnale et la vitesse de circulation dans les grands pays de 1'OCIn A. Blundell-Wignall, M. Rondoni and H. Ziegelschmidt

14. The Conduct of Monetary Pollcy in the Current Recovery La conduite de la politique monétaire dans la phase actuelle de reprise économique Paul Atkinson and Jean-Claude Chouraqui

15. Structural Budget Deficits and Fiscal stance (out of print) Déflclts budgétaires structurels et orientation de la politique budgétaire (épulsć) Patrice Muller and Robert W.R. Price

16. Monetary Policy in the OECD INTERLINK Model La politlque monétalre dans le modèle INTERLINK

A. Blundell-Wignall, M. Rondoni, H. Ziegelschmidt and J. Morgan

17. Real Gross Product in OECD Countries and Associated Purchasing Power Parities fout of print)

Produit brut réel et parttés de pouvoir d'achat dans les pays de l'OCDE (ćpuisé) Peter Hill

18. The OECD Compatible Trade and Production Data Base (out of print) Base de données compatibles sur le commerce et la production de l'OCDE: Derek Blades and Wendy Simpson

19. Nominal Wage Determination in Ten OECD Economies Détermination des salaires nominaux dans dix économies de 1'OCDE David T. Coe and Francesco Gagliardi

20. Profits and Rates of Return in OECD Countries Profits et taux de rendement dans les pays Membres de l'OCDE: James H. Chan-Lee and Helen Sutch

21. Real Interest Rates and the Prospects for Durable Growth

Taux d'intérêt réels et perspectives de croissance durable Paul Atkinson and Jean-Claude Chouraqui

22. Energy Prices: Trends and Prospects

Les prix de l'energle : évolution et perspectives Axel Mittelstädt

23. Changes in the Composition of Output and Employment Changements dans la composition de la production et de l'emploi Axel Mittelstädt and Françoise Correia 
:1. liabour Market Flexibllity and External Price Shocks.

Flexibilité du marché du travail et chocs extérieurs sur les prix

F. Klau and $A$. MIttelstädt

2!. Discropancies Between Imports and Exports: in OECD Foreign Trade Statist ics lout of print.)

liscart entre les importations et les exportations dans les statistiques du commerce extérieur de l'OCDE

Derek Blades and Marina. Ivanov

26. Aggrogate Supply in INTERLINK: Model Specification and Emp1rical Results John llel11well, Peter Sturm, Peter Jarrett and Gérard Salou

7. Commodity prices in INTERLINK

Gorry Holtham, Tapio Saavalainen, Paul Saunders and Helen Sutch

38. Fixchangie Rates and Real Long-Term Interest Rate Differentials: Evidence for liahtecen OFici) countries

D.uvid 'T. Coe and Stephen S. Golub

29. Method of Calculating Effective Exchange Rates and Indicators of Competitiveness (out of print)

Martine. Durand

30. Public debt in a medium-term context and its implications for fiscal policy (May 1986)

Jean-Claude Chouraqui, Brian Jones and Robert Bruce Montador

31. I'he OECD compatible trade and production data base 1970-1983 (March 1986)

Anders Brodin and Derek Blades.

3\%. The formulation of monetary policy: a reassessment in the light of recent experience (March 1986)

Paul Atkinson and Jean-Claude: Chouraqui

31. Mivanismus de transmission et effets macro-économiques de la politique monétaire en France: Jes principaux ensolgnemonts econométrlques (March 1986)

Marc-Olivier Strauss-Kahn

34. Pure profit rates and Tobin's $q$ in nine OECD countries (April 1986)

James H. Chan-Lee

35. Wealth and inflation effects in the aggregate consumption funct 10 n (July 1986 ) G.H. Holtham and H. Kato

17. The government household transfer data base 1960-1984: (September 1986)

lit a Varley

$3 \%$ Internationalisation of financial markets: some implications for macroeconomic policy and for the allocation of capital (November 1986)

Mitsuhiro Fukao and Masaharu Hanazaki

13. 'l'racking the U.S, external deficit, 1980-1985: experience with the OECD INTERl,INK model (February 1987)

Pal e Richardson 
39. Monetary policy in the second half of the 1980s: how much room for manoulura?

(Eebruary 1987)

Kevin Clinton and Jean-Claude Chouraqui

40. Tax reform in OECD countrles: economlo rationale and consequence:; (Auku:it lagl) Robert P. Hagemann, Brian R. Jones and Robert Bruce Montador

41. A revised supply block for the major seven countries in INTERLINK (April L987) Peter Jarrett and Raymond Torres

42. OECD economic activity and non-oil commodity prices: reduced-form exuations lor INTERLINK (June 1987)

Gerald Holtham and Martine Durand

43. Import and export price equations for manufactures (June 1987)

Richard Herd

44. Price determination in the major seven country models in INTERLINK (JuIY $198 \%$ ) Ulrich Stiehler

45. International investment-income determination in INTERLINK: models for twenty-three OECD countries and six non-OECD regions (June 1987)

David T. Coe, Richard Herd and Marie-Christine Bonnefous

46. Recent developments in OECD's international macroeconomic modol (Juno 1981 ) Pete Rlchardson

47. A review of the simulation properties of OECD's INTERLINK Model (July 1987 ) pete Richardson

48. The medium-term macroeconomic strategy revisited (December 1987) Jean-Claude Chouraqui, Kevin Clinton and Robert Bruce Montador

49. Are commodity prices leading indicators of OECD prices? (February 1988) Martine Durand and Svelnbjörn Blöndal

50. Private consumption, inflation and the "debt neutrality hypothesis": the case of elght OECD countries (January 1988)

Giuseppe Nicoletti

51. The effects of monetary policy on the real sector: an overview of emplcical evidence for selected OECD economies (April 1988)

Jean-Claude Chouraqul, Michael Driscoll and Marc-Olivier Strauss-Kahn

52. The so-called "non-economlc" objectives of agricultural policy (April 1988)

I. Alan Winters

53. Alternative solution methods in applied general equilibrium analysis (April 1988) Richard G. Harris

54. Tests of total factor productivity measurement (June 1988)

A. Steven Englander 
5. Quantifying the economy-wide effects of agricultural policies: a general equilibrium approach (July 1988)

Jean-Marc Burniaux, François Delorme, Ian Lienert, John P. Martin and peter. Hoeller

56. On aggregation methods of purchasing power parities (November 1988 ) J.R. and M. Cuthbert

5\%. An international sectoral data base for thirteen OECD countries (November 1988) F.J.M. Meyer-zu-Schlochtein

58. Empirical research on trade liberalisation with imperfect competition: a survey (November 1988)

J. David Richardson

39. Eliminating the U.S. federal budget deficit by 1993: the interaction of monetary and fiscal policy (December 1988)

Richard Herd and Byron Ballis

60. Compatible trade and production data base: 1970-1985 (November 1988)

Claude Berthet-Bondet, Derek Blades and Annie Pin

61. Ageing populations: implications for public finances (January 1989) Robert $\mathrm{P}$. Hagemann and Giuseppe Nicoletti

62. The economic dynamics of an ageing population: the case of four oEcD economies (January 1989)

Alan J. Auerbach, Laurence J. Kotlikoff, Robert P. Hagemann and Giuseppe Nicoletti

63. Modelling housing investment for seven major OECD countries (December 1988)

Thomas Egebo and Ian Lienert

64. Revised groupings for non-OECD countries in OECD's macroeconomic model INTERLINK (January 1989)

Paul O'Brien, Laure Meuro and Arthur Camilleri

65. A post mortem on OECD short-term projections from 1982 to 1987 (February 1989 ) Byron Ballis

66. Potential output in the seven major OECD countries (May 1989)

Raymond Torres and John P. Martin

67. Saving trends and behaviour in OECD countries (June 1989)

Andrew Dean, Martine Durand, John Fallon and Peter Hoeller

68. The impact of increased government saving on the economy (June 1989)

Richard Herd

69. The information content of the terms structure of interest rates: theory and practice (September 1989)

Frank Browne and Paolo Manasse

70. On the sequencing of structural reforms (September 1989)

Sebastian Edwards 
71. Modelling business sector supply for the smaller OECD countries (October 1989) Raymond Torres, Peter Jarrett and Wim Suyker

72. The role of indicators in structural surveillance (January 1990)

73. The saving behaviour of Japanese households (January 1990)

Kenichi Kawasaki

74. Industrial subsidies in the OECD economies (January 1990)

Robert Ford and Wim Suyker

75. Measuring industrial subsidies: some conceptual issue (February 1990)

Neil Bruce

76. The dollar position of the non-U.S. private sector, portfolio effects, and the exchange rate of the dollar (February 1990)

Bixio Barenco

77. Monetary policy in the wake of financial liberalisation (April 1990)

Adrian Blundell-Wignall, Frank Browne and Paolo Manasse

78. Indicators of fiscal policy: a re-examination (April 1990)

Jean-Claude Chouraqui, Robert p. Hágemann and Nicola Sartor

79. Suggestions for a new set of fiscal indicators (April 1990)

Olivier Blanchard (MIT and NBER)

80. Fiscal indicators (April 1990)

Edward E. Gramlich, The University of Michigan

81. Financial liberalisation and consumption smoothing (forthcoming)

Adrian Blundell-Wignall, Frank Browne and Stefano Cavaglia

82. Economies and the environment: a survey of issues and policy options (July 1990) Jon Nicolaisen and Peter Hoeller

83. Exchange rate policy in advanced commodity-exporting countries: the case of Australia and New Zealand (July 1990)

Adrian Blundell-Wignall and Robert G. Gregory

84. WALRAS -- A multi-sector, multi-country applied general equilibrium model for quantifying the economy-wide effects of agricultural policies: a technical manual (August 1990)

Jean-Marc Burniaux, Erançois Delorme, Ian Lienert and John P. Martin

85. Simulating the OECD INTERLINK Model under Alternative Monetary

Policy Rules (October 1990)

Pete Richardson

86. Modelling wages and prices for the smaller OECD countries (October 1990)

Kenichi Kawasaki, Peter Hoeller, Pierre Poret

87. The "PUZZLE" of wage moderation in the 1980 s (November 1990)

Pierre Poret

88. Business investment in the OECD economies: recent performance and some implications for policy (November 1990)

Robert Ford, Pierre Poret

89. A Survey of Studies of the Costs of Reducing

Greenhouse Gas Emissions (December 1990)

Peter Hoeller, Andrew Dean and Jon Nicolaison 
90. The Public Sector: Issues for the 1990s (December, 1990)

Howard Oxley, Maria Maher, John P. Martin, Giuseppe Nicoletti and Patricia Alonso-Gamo

$\underline{1991}$

91. Infrastructure and Private-Sector Productivity (January 1991) Robert Ford and Pierre Poret

92. Unemployment Persistence and Insider-Outsider Forces in Wage Determination (February, 1991)

Bertil Holmlund 